Article

\title{
Proteomic Investigation to Identify Anticancer Targets of Nemopilema nomurai Jellyfish Venom in Human Hepatocarcinoma HepG2 Cells
}

\author{
Indu Choudhary ${ }^{1}$, Hyunkyoung Lee ${ }^{1}$, Min Jung Pyo ${ }^{1}$, Yunwi Heo ${ }^{1}$, Jinho Chae ${ }^{2}$, \\ Seung Shic Yum ${ }^{3,4}$, Changkeun Kang ${ }^{1,5}$ and Euikyung Kim 1,6,* \\ 1 College of Veterinary Medicine, Gyeongsang National University, Jinju 52828, Korea; \\ induchoudhary2u@gmail.com (I.C.); leehy@gnu.ac.kr (H.L.); sacura8703@nate.com (M.J.P.); \\ yunwi0510@naver.com (Y.H.); ckkang@gnu.ac.kr (C.K.) \\ 2 Marine Environmental Research and Information Laboratory, Gunpo 15850, Korea; jinhochae@gmail.com \\ 3 South Sea Environmental Research Center, Korea Institute of Ocean Science and Technology (KIOST), \\ Geoje 53201, Korea; syum@kiost.ac.kr \\ 4 Faculty of Marine Environmental Science, University of Science and technology (UST), Geoje 53201, Korea \\ 5 Institutes of Agriculture and Life Science, Gyeongsang National University, Jinju 52828, Korea \\ 6 Institute of Animal Medicine, Gyeongsang National University, Jinju 52828, Korea \\ * Correspondence: ekim@gnu.ac.kr; Tel.: +82-55-772-2355; Fax: +82-55-772-2349
}

Received: 4 March 2018; Accepted: 27 April 2018; Published: 10 May 2018

\begin{abstract}
Nemopilema nomurai is a giant jellyfish that blooms in East Asian seas. Recently, N. nomurai venom $(\mathrm{NnV})$ was characterized from a toxicological and pharmacological point of view. A mild dose of $\mathrm{NnV}$ inhibits the growth of various kinds of cancer cells, mainly hepatic cancer cells. The present study aims to identify the potential therapeutic targets and mechanism of $\mathrm{NnV}$ in the growth inhibition of cancer cells. Human hepatocellular carcinoma (HepG2) cells were treated with $\mathrm{NnV}$, and its proteome was analyzed using two-dimensional gel electrophoresis, followed by matrix-assisted laser desorption/ionization time-of-flight mass spectrometry (MALDI/TOF/MS). The quantity of twenty four proteins in NnV-treated HepG2 cells varied compared to non-treated control cells. Among them, the amounts of fourteen proteins decreased and ten proteins showed elevated levels. We also found that the amounts of several cancer biomarkers and oncoproteins, which usually increase in various types of cancer cells, decreased after $\mathrm{NnV}$ treatment. The representative proteins included proliferating cell nuclear antigen (PCNA), glucose-regulated protein 78 (GRP78), glucose-6-phosphate dehydrogenase (G6PD), elongation factor $1 \gamma(\mathrm{EF} 1 \gamma)$, nucleolar and spindle-associated protein (NuSAP), and activator of $90 \mathrm{kDa}$ heat shock protein ATPase homolog 1 (AHSA1). Western blotting also confirmed altered levels of PCNA, GRP78, and G6PD in NnV-treated HepG2 cells. In summary, the proteomic approach explains the mode of action of $\mathrm{NnV}$ as an anticancer agent. Further characterization of $\mathrm{NnV}$ may help to unveil novel therapeutic agents in cancer treatment.
\end{abstract}

Keywords: jellyfish; Nemopilema nomurai; HepG2 cell; venom; proteomics; MALDI/TOF/MS; 2-DE

Key Contribution: Nemopilema nomurai venom can induce apoptosis of cancer cells at the proteome level. $\mathrm{NnV}$ treatment diminished the levels of proteins involved in DNA replication, cell cycle progression, transcription, tumor cell proliferation, apoptosis resistance, tumor metastasis, and angiogenesis. 


\section{Introduction}

Annual reports on public safety are raising concerns about jellyfish envenomation. Jellyfish stings are leading to a deleterious public health threat worldwide. Our ecosystem has different kinds of venomous animals, including terrestrial, such as snake, scorpion, spider, centipede, etc., and aquatic organisms, such as sea anemone, fire coral, and jellyfish [1,2]. Venomous jellyfish species are found in both cubozoans, such as Chironex fleckeri, and scyphozoans (Cyanea capillata, Pelagia noctiluca, and Nemopilema nomurai) [3-6]. We have focused on Nemopilema nomurai in this study; it is one of the largest jellyfish species and can grow up to $2 \mathrm{~m}$ in bell diameter and $200 \mathrm{~kg}$ in weight [7]. The giant jellyfish N. nomurai is endemic to the East Asian marginal seas, being principally distributed in the Bohai Sea, Yellow Sea, Northern East China Sea, and the coasts of Korea and Japan [8]. Envenomation by $N$. nomurai can result in a dermatological reaction with an intense burning sensation and erythematous eruption [9]. N. nomurai envenomation can also be accompanied by other types of toxicological symptoms, such as cardiotoxicity, hemolytic activity, and cytotoxic effects [6,10].

Venoms usually contain a complex mixture of hundreds of bioactive components which include small molecules, biogenic amines, peptides, and proteins [11]. Therefore, the venoms of many organisms have been investigated as a source of novel pharmacological reagents, including anticancer drugs. Current advancements in the field of proteomics and genomic research have generated a platform for the discovery of bioactive pharmaceutical components, although many researchers have evaluated the therapeutic effect of several animal venoms [12]. The existing toxicological and pharmacological research provides a broad perspective for the drug development industry, proving that these venoms and their active components can be potential sources of novel therapeutic agents.

It was previously reported that scorpion venom can inhibit the proliferation of cancer cells and primary tumors in animal models and can serve as a potential anticancer therapeutic $[13,14]$. Earlier research has reported that the sea anemone Heteractis magnifica can induce apoptosis and cell cycle arrest in lung cancer cell lines [15]. A number of studies have also demonstrated that snake venom has a strong anti-proliferative activity and antitumor effect in both in vitro and in vivo models [16,17]. Recent research has suggested that Macrothele raveni spider venom can induce apoptosis and inhibit the growth of leukemic K562 cells by activating caspase 3 and caspase 8 [18]. Bee venom can also effectively inhibit tumor growth. Bee venom therapy may provide beneficial effects against various types of cancer [19]. The synthetic compound Glycosphingolipid 7, which was identified in millipede Parafontaria laminata armigera, has an antiproliferative effect on the proliferation of melanoma (B16F10 cell lines) by suppressing the activation of the FAK-AKT and ERK1/2 pathways [20]. Moreover, a few studies have described the antitumor activity of caterpillar venom. Cecropins are set of peptides recognized in the hemolymph of the giant silkmoth (Hyalophora cecropia) which display anticancer activity against different types of tumor cell lines [21]. Additionally, a cardiotonic steroid (bufalin) extracted from toad venom (Bufo gargarizans cantor) exerts antitumor activity against numerous human cancer cell lines by inducing apoptosis and cell cycle arrest [22]. These characteristics of scorpion, snake, spider, and sea anemone venoms make them as a valuable source of therapeutic agents in cancer research. 
It has been suggested that the venom of jellyfish Chrysaora quinquecirrha (sea nettle) has anti-tumor and antioxidant activities against Ehrlich ascites carcinoma (EAC) tumor cells [23]. Earlier, it had been demonstrated that Nemopilema nomurai has antioxidant activity, and that freeze-dried powder could provide potential human health benefit [24]. Jellyfishes belonging to the order Rhizostomeae are mainly used as food in Asia, especially in China and Japan, Nemopilema nomurai and Rhopilema esculentum also belongs to same order [25]. The Food and Agriculture Organization (FAO) of the United Nations has reported that jellyfish biomass can be used as a bioactive ingredient in food or medicine [25]. N. nomurai collagen extract can trigger the production of immunoglobulins and cytokines without causing allergic reactions, demonstrating its immune-regulatory role [26]. Jellyfish glycoprotein qniumucin can prevent articular cartilage degeneration in in vivo studies using an osteoarthritis (OA) model [27]. Our most recent report demonstrated that $\mathrm{NnV}$ exerts highly selective cytotoxicity in HepG2 cells via dual inhibition of the Akt and mTOR signaling pathways, but normal cells remained unaffected [28]. In the present work, we have analyzed the potential therapeutic targets of $\mathrm{NnV}$ at the proteomic level for the first time.

We found that the proliferation of HepG2 cells was significantly inhibited by $\mathrm{NnV}$ in a concentration- and time-dependent manner. In addition, we utilized two-dimensional gel electrophoresis (2-DE) coupled with matrix-assisted laser desorption/ionization time-of-flight mass spectrometry (MALDI/TOF/MS) to identify proteins with an altered abundance in HepG2 cells treated with $\mathrm{NnV}$, in order to elucidate the molecular mechanisms involved in $\mathrm{NnV}$ anticancer therapy. The change in levels of the major proteins was also validated by Western blotting. The proteins demonstrating an altered abundance after $\mathrm{NnV}$ treatment may provide clues for future molecular research on the anticancer effect of $\mathrm{NnV}$.

\section{Results and Discussion}

\subsection{NnV Induces Cytotoxicity in HepG2 Cell Lines}

A MTT (3-(4,5-dimethyl-2-yl)-2,5-diphenyltetrazolium bromide) assay was used to determine the cytotoxic effect of $\mathrm{NnV}$ on HepG2 cells. Briefly, HepG2 cells were treated with increasing concentrations $(0.8-1.6 \mu \mathrm{g} / \mathrm{mL})$ of $\mathrm{NnV}$ for different time periods $(6,12$, and $24 \mathrm{~h})$. Compared with the control without $\mathrm{NnV}$ treatment, the viability of HepG2 cells decreased with $\mathrm{NnV}$ treatment in a concentration- and time-dependent manner, as shown in Figure 1A. When the cells were exposed to lower concentrations $(0.8$ and $1 \mu \mathrm{g} / \mathrm{mL})$ of $\mathrm{NnV}$ there was no significant difference in cell viability at 6, 12, or $24 \mathrm{~h}$ post-treatment. After $24 \mathrm{~h}$ of incubation with $\mathrm{NnV}$ at concentrations of 1.2, 1.4, and $1.6 \mu \mathrm{g} / \mathrm{mL}$, cell proliferation decreased to $56.3 \%, 38.1 \%$, and $29.4 \%$, respectively. Treatment with $1.2 \mu \mathrm{g} / \mathrm{mL}$ of NnV for $24 \mathrm{~h}$ resulted in a significant decrease in cell viability compared with that of the control without $\mathrm{NnV}$ treatment. The IC50 value of $\mathrm{NnV}$ concentration needed for $50 \%$ inhibition of cell proliferation was determined to be $1.2 \mu \mathrm{g} / \mathrm{mL}$ using probit analysis. This concentration was used for further experiments. For proteomic analysis, we treated HepG2 cells with $1.2 \mu \mathrm{g} / \mathrm{mL}$ (IC50 value) of NnV. The phase contrast microscopic analysis was performed to examine the morphological characteristics of HepG2 cells (Figure 1B). In comparison to the control, NnV treated HepG2 cells showed cell shrinkage, loss of adhesion with round shape, necrosis, and formation of apoptotic fragments. On the other hand, HepG2 control cells grew properly and had normal growth. Our results demonstrate that NnV significantly decreased the number of viable cells in a concentration- and time-dependent manner and had antiproliferative activity. 


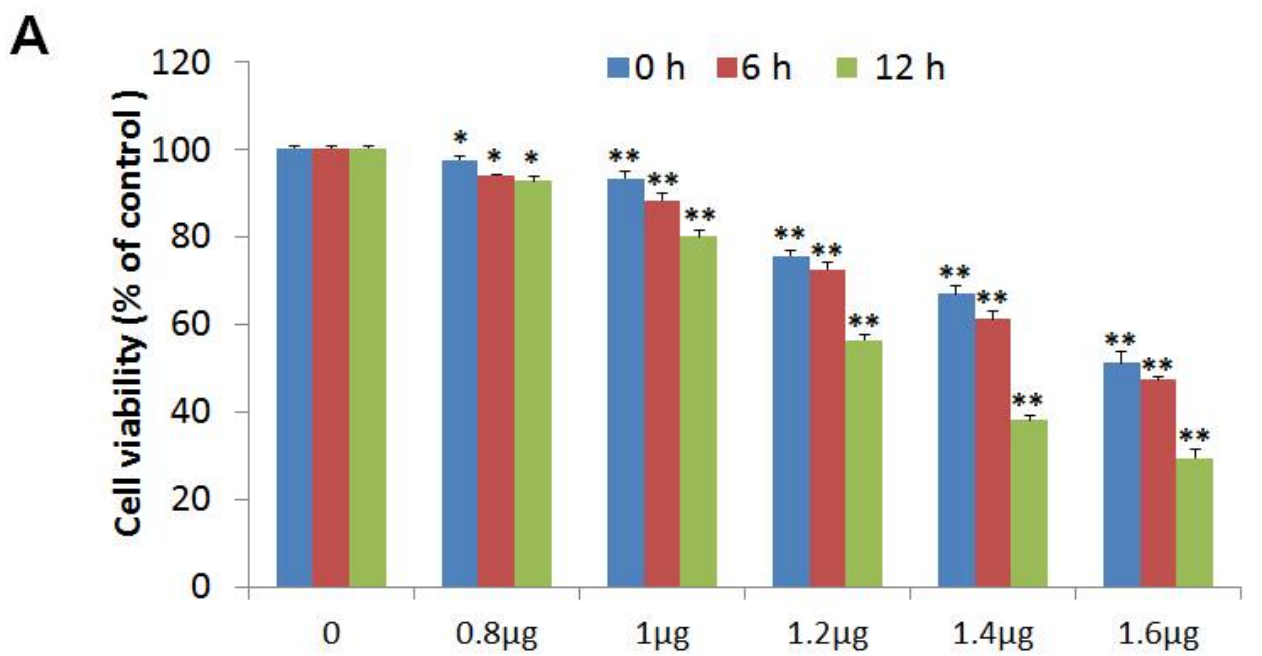

B

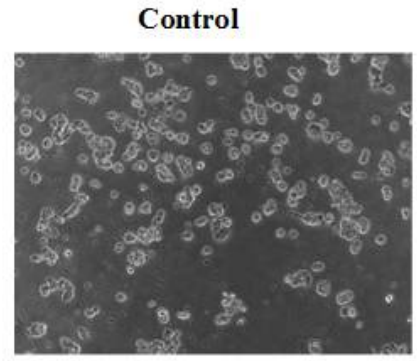

$6 \mathrm{~h}$

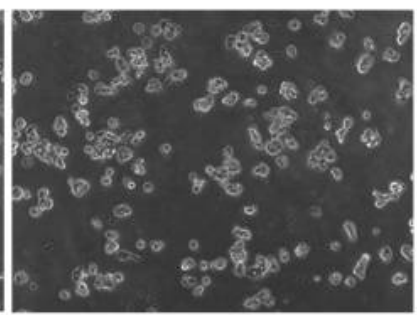

$12 \mathrm{~h}$

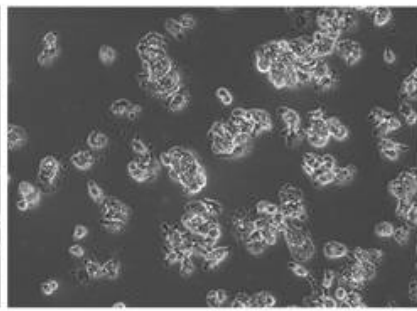

Figure 1. Nemopilema nomurai jellyfish venom $(\mathrm{NnV})$ inhibits proliferation of HepG2 hepatocellular carcinoma cells. (A) HepG2 cells were treated with various concentrations of $\mathrm{NnV}$ for 6, 12, and $24 \mathrm{~h}$ and the cell viabilities were determined by a 3-(4,5-dimethyl-2-yl)-2,5-diphenyltetrazolium bromide (MTT) Assay; (B) cell morphological changes were observed using a phase contrast microscope. The left side panel is showing the untreated HepG2 cells (Control); in the middle HepG2 cells were treated with NnV at a concentration of $1.2 \mu \mathrm{g} / \mathrm{mL}$ for $6 \mathrm{~h}$; on the right cells were treated for $12 \mathrm{~h}$ with same concentration. Bar graphs are the mean $\pm \mathrm{SD}$ of the triplicate independent experiments. The ${ }^{*}$ asterisk indicates a significant difference compared with control ${ }^{*} p<0.05,{ }^{* *} p<0.01$.

\subsection{D PAGE Analysis of Untreated and NnV Treated H9c2 Cells}

To investigate in depth molecular changes at protein level after $\mathrm{NnV}$ treatment we performed comparative proteomic analysis to determine protein level changes between HepG2 cells treated with or without $\mathrm{NnV}$ at IC50 for 6 or $12 \mathrm{~h}$. To determine which proteins had altered abundance in HepG2 cells after NnV treatment proteins from the control and NnV treated HepG2 cells ( $6 \mathrm{~h}$ and $12 \mathrm{~h}$ ) were examined by 2-DE. Three biological replicates of the experiment were performed to obtain the reproducibility of the gels. Approximately 1000 protein spots were visualized after silver staining. All gels were run in triplicates. The patterns of 2-DE spots present in all gels from the three independent experiments showed no significant differences, corroborating the reproducibility of our experiment. In Figure 2, representative 2-DE images of control and $\mathrm{NnV}$ treated ( 6 and $12 \mathrm{~h}$ ) protein samples of HepG2 cells are shown. All 2-DE gel images were scanned and analyzed using Progenesis Same Spots software (Nonlinear Dynamics, New Castle, UK). After performing automatic spot detection and image analysis, 70 protein spots with a $\geq 1.5$ fold change in intensity were found with differential abundances and statistical significance (ANOVA $p$-value $\leq 0.05$ ). Representative fused 2-DE gel images of the control and $\mathrm{NnV}$ treated samples $(6 \mathrm{~h}$ and $12 \mathrm{~h}$ ) are shown in Figure 3 . These 70 differentially expressed protein spots were subjected to MALDI/TOF/MS analysis. 


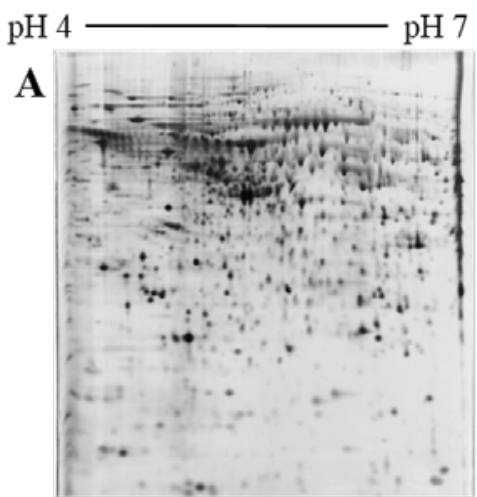

Control

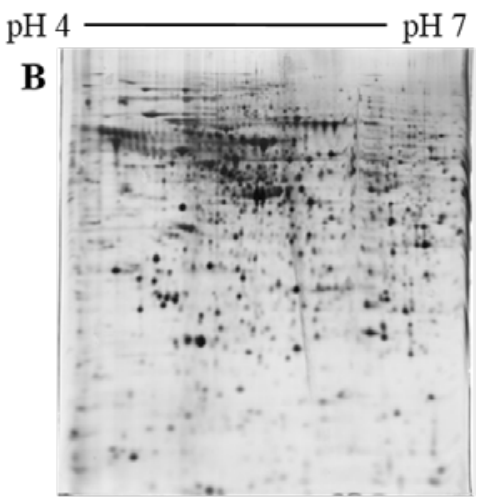

$6 \mathrm{~h}$

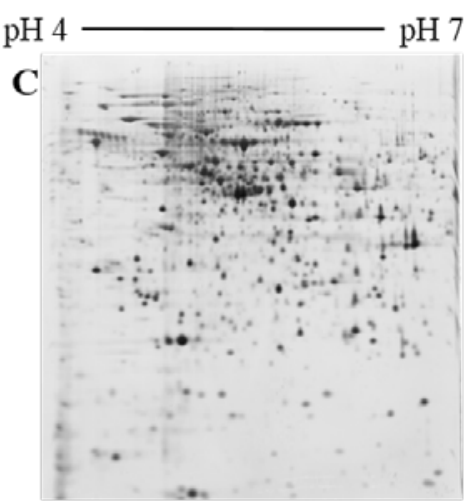

$12 \mathrm{~h}$

Figure 2. Comparison of patterns shown by two-dimensional gel electrophoresis (2-DE) images between HepG2 cells. (A) Control; (B) treated with $\mathrm{NnV}$ at a concentration of $1.2 \mu \mathrm{g} / \mathrm{mL}$ for $6 \mathrm{~h}$ and (C) $12 \mathrm{~h}$. For the first dimension, $300 \mu \mathrm{g}$ of total protein was resolved on $18 \mathrm{~cm}$ IPG dry strips ( $\mathrm{pH} 4-7 \mathrm{~L}$ ), and the second dimension was carried out using 12\% SDS-PAGE gels. 2-DE gels were silver stained and scanned by an Epson perfection V 700 photo scanner. Three independent replicate gels were run for further statistical analysis.

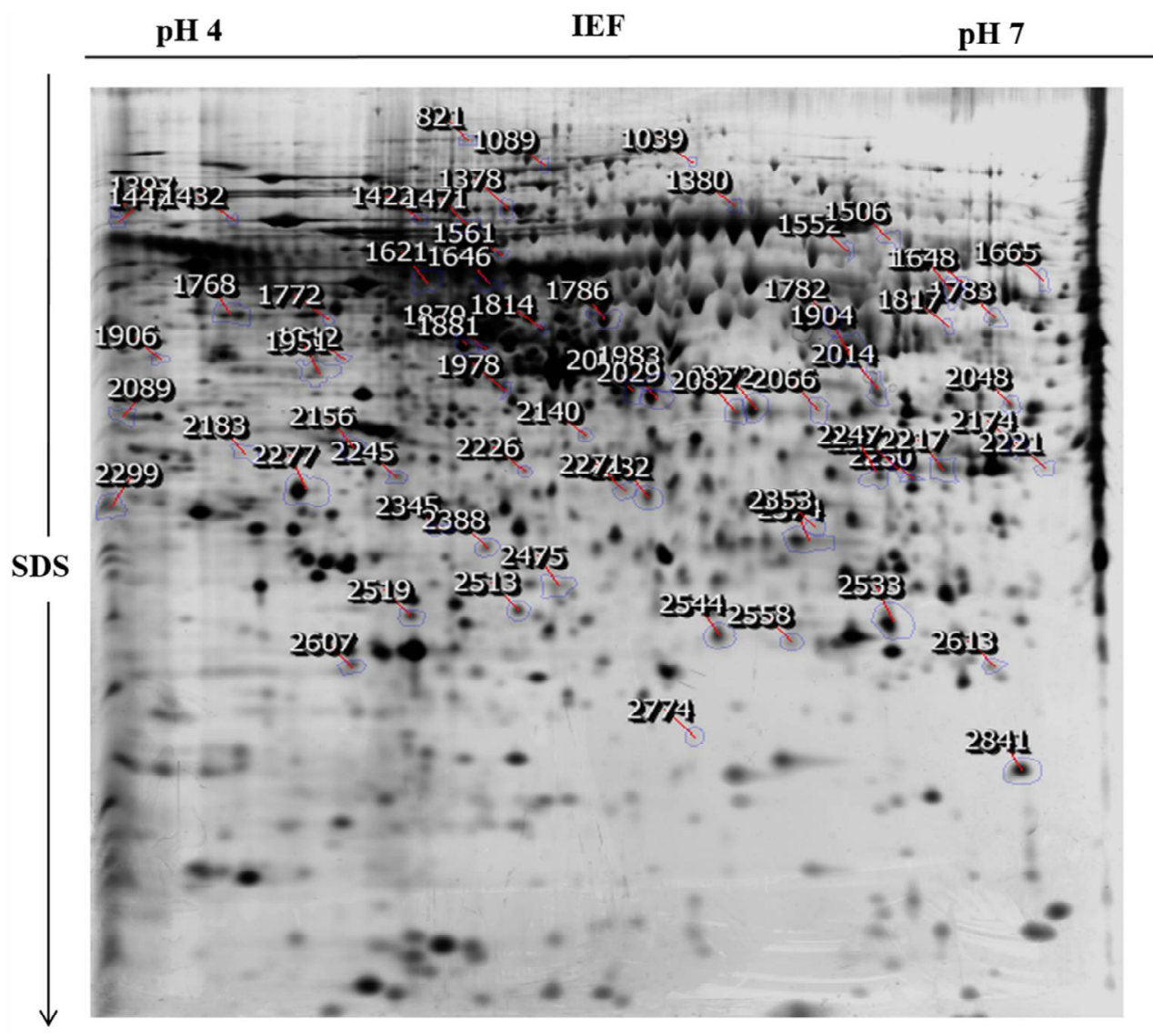

Figure 3. Image of 2-DE proteomic analysis of $\mathrm{NnV}$ treated HepG2 cells. The representative 2D image was generated using Progenesis Same Spots software, and protein spots were further analyzed by matrix-assisted laser desorption/ionization time-of-flight mass spectrometry (MALDI/TOF/MS). The position of differentially expressed proteins was assigned with blue boundaries and red arrows. Protein spots with numbers were hand-picked to perform in-gel digestion. 


\subsection{Identification of the Differential Abundant Proteins by MALDI/TOF/MS and Western Blotting}

The 70 differentially expressed proteins were excised manually from the 2-DE gels for MALDI/TOF/MS analysis. Of the 70 protein spots, only 24 proteins were successfully identified by MALDI/TOF/MS. Results are shown in Table 2. Of the 24 proteins identified by MALDI/TOF/MS, the amounts of 14 proteins reduced, while 10 proteins showed an increased abundance with $\mathrm{NnV}$ treatment. The relative spot intensity of these differentially expressed proteins, as well as their fold change and P values, were summarized in the Supplementary Materials Tables S1 and S2, respectively. One of the 14 proteins with decreased abundance was PCNA. PCNA plays a pivotal role in numerous cellular processes, for instance DNA replication, cell cycle progression, transcription, and chromosome segregation [29-31]. Consequently, it has been previously reported that the expression level of PCNA was higher in cancer cells and cancer tissues, such as breast, gastric, and lung cancer [32-35]. It has been found that novel classes of the compound known as PCNA inhibitor (PCNA-I1) can directly bind to PCNA, stabilize PCNA trimers, decrease PCNA-chromatin association, and inhibit tumor cell growth by inducing a cell cycle arrest [36]. Overexpression of PCNA is a remarkable biomarker for tumor diagnosis $[32,33]$. Thus, PCNA might be a possible target for cancer therapy. In the present study, the protein level of PCNA significantly decreased in response to NnV treatment, which was further confirmed by Western blot analysis (Figure 4). Hence, the reduced amount of PCNA in NnV treated HepG2 cells might contribute to the antiproliferative and anticancer effect of NnV.

Another protein with a reduced amount, identified by proteomic analysis in this study, was glucose-regulated protein 78 (GRP78). GRP78 belongs to the heat shock protein 70 (HSP70) family. It is best known as a immunoglobulin heavy chain binding protein (BiP) [37]. GRP78 is mainly located in the lumen of the endoplasmic reticulum and acts as a molecular chaperone. It also resides in the plasma membrane, cytoplasm, mitochondria, and nucleus. Furthermore, it is present in the cellular secretions of tumor cells [38]. GRP78 is involved in protein folding and assembly, degradation of the targeted misfolded protein, ER Ca ${ }^{2+}$ binding, and the regulation of the activation of transmembrane ER-stress sensors [38,39]. It also has antiapoptotic properties [39,40]. GRP78 is also involved in tumor cell proliferation, apoptosis resistance, tumor metastasis, and angiogenesis [41]. Hence, it plays a vital role in cancer development. GRP78 overexpression can result in opposition to a wide range of chemotherapeutic agents in the different classes of tumor, including lung, bladder, gastric, breast stomach, and epidermoid carcinoma [42-46]. It has been reported that knockdown of GRP78 can inhibit tumor cell proliferation and suppress metastasis and growth in xenograft models [47]. Our 2 DE results revealed that amount of GRP78 was significantly reduced in NnV treated HepG2 cells; this was confirmed by Western Blot analysis (Figure 4). Therefore, a reduced level of GRP78 in NnV treated HepG2 cells might have induced apoptosis and conferred the anticancer effect of $\mathrm{NnV}$. 
Table 1. Identification of differentially expressed proteins using MALDI/TOF/MS from HepG2 cells treated with N. nomurai venom.

\begin{tabular}{|c|c|c|c|c|c|c|c|}
\hline Spot No ${ }^{1}$ & Accession Number ${ }^{2}$ & Protein Name & Theoretical MW/Pi ${ }^{3}$ & Mascot Score $^{4}$ & Coverage $\%^{5}$ & Matched Peptides $^{6}$ & Biological Features \\
\hline \multicolumn{8}{|c|}{ Down-regulated Proteins } \\
\hline 2277 & PCNA_HUMAN & $\begin{array}{l}\text { Proliferating cell } \\
\text { nuclear antigen }\end{array}$ & $29,092 / 4.57$ & 144 & $72 \%$ & 16 & DNA repair, DNA Regulation, and mismatch repair. \\
\hline 1648 & KIF28_HUMAN & $\begin{array}{l}\text { Kinesin like protein } \\
\text { KIF 28P }\end{array}$ & $109,098 / 8.68$ & 58 & $9 \%$ & 8 & $\begin{array}{l}\text { Mitochondrian organization and organelle transport } \\
\text { along microtubule. }\end{array}$ \\
\hline 2299 & GRP78_HUMAN & $\begin{array}{l}78 \mathrm{kDa} \text { glucose } \\
\text {-regulated protein }\end{array}$ & $72,402 / 5.07$ & 69 & $17 \%$ & 9 & $\begin{array}{l}\text { Negative regulation of the apoptotic process and } \\
\text { negative regulation of transforming growth factor beta } \\
\text { receptor signaling pathway. }\end{array}$ \\
\hline 2008 & AHSA1_HUMAN & $\begin{array}{l}\text { Activator of } 90 \mathrm{kDa} \\
\text { heat shock protein } \\
\text { ATPase homolog } 1\end{array}$ & $38,421 / 5.41$ & 72 & $28 \%$ & 9 & Positive regulation of ATPase activity. \\
\hline 1768 & NUSAP_HUMAN & $\begin{array}{l}\text { Nucleolar and } \\
\text { spindle-associated } \\
\text { protein } 1\end{array}$ & $49,593 / 9.92$ & 61 & $32 \%$ & 12 & $\begin{array}{l}\text { Establishment of mitotic spindle localization, mitotic } \\
\text { chromosome condensation, and positive regulation } \\
\text { of mitosis. }\end{array}$ \\
\hline 2245 & NDUF7_HUMAN & $\begin{array}{l}\text { NADH } \\
\text { dehydrogenase } \\
\text { [ubiquinone] complex } \\
\text { 1, assembly factor } 7\end{array}$ & $49,435 / 8.47$ & 68 & $11 \%$ & 5 & $\begin{array}{l}\text { Methylation, mitochondrial respiratory complex } 1 \\
\text { assembly, and methyltransferase activity. }\end{array}$ \\
\hline 1978 & DNM1L_HUMAN & $\begin{array}{l}\text { Dynamin-1-like } \\
\text { protein }\end{array}$ & $82,339 / 6.37$ & 57 & $14 \%$ & 6 & $\begin{array}{l}\text { Positive regulation of the apoptotic process and positive } \\
\text { regulation of intrinsic apoptotic signaling pathway. }\end{array}$ \\
\hline 2183 & ATLA3_HUMAN & Atlastin-3 & $60,960 / 5.43$ & 58 & $10 \%$ & 6 & $\begin{array}{l}\text { GTP catabolic process, golgi organization, endoplasmic } \\
\text { reticulum organization and, homooligomerization. }\end{array}$ \\
\hline 1772 & HNRH1_HUMAN & $\begin{array}{l}\text { Heterogeneous } \\
\text { nuclear } \\
\text { ribonucleoprotein } \mathrm{H}\end{array}$ & $49,484 / 5.89$ & 74 & $33 \%$ & 10 & $\begin{array}{l}\text { RNA Processing, regulation of RNA splicing, POLY(A) } \\
\text { RNA binding, and poly(U) RNA binding. }\end{array}$ \\
\hline 1817 & EF1G_HUMAN & $\begin{array}{l}\text { Elongation factor } \\
\text { 1-gamma }\end{array}$ & $50,429 / 6.25$ & 58 & $15 \%$ & 6 & $\begin{array}{l}\text { Translational elongation, cellular protein metabolic } \\
\text { process, translation, and gene expression. }\end{array}$ \\
\hline \multicolumn{8}{|c|}{ Up-regulated Proteins } \\
\hline 1665 & G6PD_HUMAN & $\begin{array}{l}\text { Glucose-6-phosphate } \\
\text { 1-dehydrogenase }\end{array}$ & $59,675 / 6.39$ & 82 & $16 \%$ & 8 & $\begin{array}{l}\text { Pentose-phosphate shunt, oxidative branch, Glucose } \\
\text { 6-phosphate metabolic process, NADP metabolic } \\
\text { process, and NADPH (nicotinamide adenine } \\
\text { dinucleotide phosphate-oxidase) regeneration. }\end{array}$ \\
\hline 2245 & ATP23_HUMAN & $\begin{array}{l}\text { Mitochondrial inner } \\
\text { membrane protease } \\
\text { ATP23 homolog }\end{array}$ & $28,690 / 8.30$ & 57 & $29 \%$ & 4 & $\begin{array}{l}\text { Double strand break via non homologous end joining } \\
\text { and protein phosphorylation. }\end{array}$ \\
\hline
\end{tabular}


Table 2. Identification of differentially expressed proteins using MALDI/TOF/MS from HepG2 cells treated with N. nomurai venom.

\begin{tabular}{|c|c|c|c|c|c|c|c|}
\hline Spot No ${ }^{1}$ & Accession Number ${ }^{2}$ & Protein Name & Theoretical $\mathbf{M W} / \mathbf{P i}^{3}$ & Mascot Score $^{4}$ & Coverage $\%^{5}$ & Matched Peptides $^{6}$ & Biological Features \\
\hline 2089 & DNM3A_HUMAN & $\begin{array}{l}\text { DNA } \\
\text { (Cytosine-5)-methyltrans } \\
\text { 3A }\end{array}$ & sfengs $390 / 6.19$ & 58 & $18 \%$ & 16 & $\begin{array}{l}\text { DNA methylation, } S \text {-adenosylhomocysteine } \\
\text { metabolic process, regulation of } \\
\text { transcription from RNA poly II promoter, } \\
\text { and regulation of gene expression by } \\
\text { genetic imprinting. }\end{array}$ \\
\hline 1648 & TYW1_HUMAN & $\begin{array}{l}\text { S-adenosyl-L-methionine } \\
\text { tRNA } \\
\text { 4-demethylwyosine } \\
\text { synthase }\end{array}$ & $\begin{array}{l}\text { e-dependent } \\
84,732 / 6.42\end{array}$ & 57 & $7 \%$ & 7 & tRNA processing. \\
\hline 1646 & CP21A_HUMAN & $\begin{array}{l}\text { Steroid } \\
\text { 21-hydroxylase }\end{array}$ & $56,251 / 7.71$ & 57 & $11 \%$ & 5 & $\begin{array}{l}\text { Glucocorticoid biosynthetic process and } \\
\text { steroid metabolic process. }\end{array}$ \\
\hline 2353 & AICDA_HUMAN & $\begin{array}{l}\text { Single-stranded DNA } \\
\text { cytosine deaminase }\end{array}$ & $24,337 / 9.50$ & 68 & $47 \%$ & 9 & $\begin{array}{l}\text { mRNA processing, DNA demethylation, cell } \\
\text { differentiation, and protein binding. }\end{array}$ \\
\hline 1906 & UBP15_HUMAN & $\begin{array}{l}\text { Ubiquitin } \\
\text { carboxyl-terminal } \\
\text { hydrolase } 15\end{array}$ & $113,602 / 5.06$ & 56 & $18 \%$ & 10 & $\begin{array}{l}\text { Transforming growth factor beta receptor } \\
\text { signaling pathway, BMP signaling pathway, } \\
\text { and protein deubiquitination. }\end{array}$ \\
\hline 2029 & PI4KA_HUMAN & $\begin{array}{l}\text { Phosphatidylinositol } \\
\text { 4-kinase alpha }\end{array}$ & $233,622 / 6.43$ & 70 & $28 \%$ & 62 & $\begin{array}{l}\text { Signal transduction, } \\
\text { phosphatidylinositol-mediated signaling, } \\
\text { and phospholipid metabolic process. }\end{array}$ \\
\hline 2014 & SYHC_HUMAN & Histidine-tRNA ligase & $57,944 / 5.72$ & 64 & $34 \%$ & 17 & $\begin{array}{l}\text { Histidyl-tRNA aminoacylation, cellular } \\
\text { metabolism, tRNA amino acylation for } \\
\text { protein translation, and protein biosynthesis. }\end{array}$ \\
\hline 821 & DHB13_HUMAN & $\begin{array}{l}\text { 17-beta-hydroxysteroid } \\
\text { dehydrogenase } 13\end{array}$ & $33,976 / 9.14$ & 65 & $46 \%$ & 10 & Oxidoreductase activity. \\
\hline 2841 & SARM1_HUMAN & $\begin{array}{l}\text { Sterile alpha and TIR } \\
\text { motif-containing } \\
\text { protein } 1\end{array}$ & $80,365 / 6.14$ & 57 & $20 \%$ & 9 & $\begin{array}{l}\text { Toll like receptor signaling pathway, } \\
\text { regulation of dendrite morphogenesis, and } \\
\text { regulation of neuron death. }\end{array}$ \\
\hline 2282 & ZSC31_HUMAN & $\begin{array}{l}\text { Zinc finger and SCAN } \\
\text { domain-containing } \\
\text { protein } 31\end{array}$ & $48,233 / 6.42$ & 63 & $14 \%$ & 5 & Transcription and transcription regulation. \\
\hline 2217 & PAR3L_HUMAN & $\begin{array}{l}\text { Partitioning defective } \\
3 \text { homolog B }\end{array}$ & $133,097 / 8.54$ & 72 & $11 \%$ & 11 & Cell cycle and cell division. \\
\hline 1378 & GARL3_HUMAN & $\begin{array}{l}\text { GTPase-activating } \\
\text { Rap/Ran-GAP } \\
\text { domain-like protein } 3\end{array}$ & $113,808 / 7.57$ & 60 & $9 \%$ & 8 & $\begin{array}{l}\text { Regulation of small GTPase mediated } \\
\text { signal transduction. }\end{array}$ \\
\hline
\end{tabular}

${ }^{1}$ Spot number as given in 2-DE master gels; ${ }^{2}$ accession number as in SwissProt database; ${ }^{3}$ theoretical mass (MW) and Pi revealed in SwissProt database; ${ }^{4}$ according to SwissProt database mascot score higher than 56 and $p<0.05$ from Mascot search on proteomics data were considered; ${ }^{5}$ Percentage of amino acids sequence coverage of matched peptides for the identified proteins; ${ }^{6}$ Number of peptides matched by MALDI-TOF/MS for each identified protein. 
Glucose-6-phosphate dehydrogenase (G6PD), a central enzyme in the pentose phosphate pathway was also identified in the present study. It can generate NADPH and ribose-5-phosphate in rapidly growing cells, which is necessary for the synthesis of RNA and DNA [48]. The generated NADPH serves as a vital component for glycolysis and is involved in various reductive biosynthetic reactions. Glycolysis maintains the levels of glutathione required to carry out the detoxification of free radicals and peroxides [49,50]. Consequently, G6PD might be able to induce cancer cell survival and growth through the pentose phosphate pathway by creating NADPH and ribose [51-53]. Moreover, G6PD expression is highly elevated in numerous types of cancers such as breast, colon, leukemia, melanoma, cervical, prostatic, and endometrial cancers [54-56]. Previous studies have shown that ectopic expression of G6PD in anchorage-independent NIH 3T3 cells resulted in higher levels of NADPH and glutathione which promoted cell growth [57]. Moreover, in nude mice, G6PD gene transformed NIH 3 T3 cells showed tumorigenic properties, indicating that G6PD may act as a possible oncogene [58]. The up-regulated level of G6PD in various categories of cancer cells suggests that G6PD might have potential future applications as a diagnostic and prognostic marker in cancer therapy. A recent report has demonstrated that after RNA interference and down-regulation of G6PD in the IFN signaling pathway HBV replication is reduced five-fold, while overexpression of G6PD resulted in the amendment of the IFN signaling pathway [59]. Recent research has revealed that dehydroepiandrosterone (DHEA) and shRNA technologies can inhibit G6PD activity, increase apoptosis, and decrease the proliferation and migration of Hela cells [60]. Buthionine sulfoximine (BSO) functions as a glutathione depletion agent, it can reduce colony formation of G6PD-overexpressing cells in soft agar [60], suggesting that G6PD inhibitors can be used potentially to repress the cancer cell growth. Therefore, G6PD might be considered as an excellent target for cancer therapy. In the current study, 2DE and MALDI/TOF/MS results showed that the protein level of G6PD was significantly reduced in HepG2 cells treated with $\mathrm{NnV}$ for 6 or $12 \mathrm{~h}$ compared with that in control.

The reduced abundance of G6PD was validated by Western blotting analysis (Figure 4), clearly indicating that $\mathrm{NnV}$ could inhibit the proliferation of HepG2 cells. Therefore, G6PD may contribute to the therapeutic function of $\mathrm{NnV}$ in cancer therapy. The present results revealed that the expression level of elongation factor $1 \gamma(\mathrm{EF} 1 \gamma)$ was decreased after $\mathrm{NnV}$ treatment. EF1 $\gamma$ is a well-known subunit of elongation factor-1 (EF-1) and has a crucial role in protein synthesis, it mediates the transport of aminoacyl tRNA to 80S ribosomes, resulting in the elongation of polypeptide chains [61]. EF- $1 \gamma$ is a substrate of the cdc2 kinase, a maturation-promoting factor that monitors entry into the M-phase of the cell cycle in all eukaryotic cells [61,62]. Previous studies have shown that EF- $1 \gamma$ mRNA is overexpressed in breast, colorectal, gastric, hepatocellular, pancreatic, and esophageal carcinoma [62-67]. Earlier clinicopathologic studies have revealed that EF-1 $\gamma$ mRNA is overexpressed in 15 of the 22 gastric carcinoma cases that tested positive for vascular permeation [64]. Moreover, 9 of 10 patients showed severe vascular permeation in histologic slides with a 10-fold higher overexpression of EFI- $\gamma$ mRNA [64]. Therefore, there is a remarkable correlation between the overexpression of EFI- $\gamma$ mRNA and vascular permeation, suggesting that the overexpression of EFI- $\gamma$ may be a valuable diagnostic marker for gastric carcinomas. In our experiment, the level of EFI- $\gamma$ protein in NnV treated HepG2 cells was reduced, suggesting its putative role in the action of $\mathrm{NnV}$ as an anticancer agent. Dynamin-related protein 1 (Drp1), a member of the dynamin family of GTPases, had a reduced amount in NnV-treated HepG2 cells. Drp1 is needed for mitochondrial fission. Drp1 expression has been reported to be up-regulated in distinct types of cancers, including breast and lung cancers [68]. The siRNA-mediated DRP1 knockdown can result in the gathering of elongated mitochondria in colon cancer cells [69]. In addition, DRP1 down-regulation can decrease the level of cell proliferation and intensify colon cancer apoptosis [69]. It has been reported that DRP1 inhibition can lesson cancer cell growth and escalate apoptosis in both in vivo and in vitro models of various cancers, including colon, breast, lung, and cervical cancers [69-72]. These findings suggest that DRP-1 can be utilized as a therapeutic target for various kinds of cancers. Our results also showed that DRP-1 protein abundance decreased in $\mathrm{NnV}$ treated HepG2 cells compared with that in the control, further 
supporting the function of $\mathrm{NnV}$ as an anticancer agent. Another protein with reduced abundance level, Nucleolar and spindle-associated protein (NuSAP), a novel microtubule-associated protein, was found in this study. NuSAP is expressed in swiftly proliferating cells, and is an essential regulator of mitosis [73]. NuSAP is involved in various biological processes, including the organization of mitotic spindle assembly, chromosome segregation, sister chromatid segregation, and cytokinesis $[73,74]$. Numerous research groups have suggested that NuSAP is associated with cancer [74]. NuSAP is elevated in hepatocellular carcinomas. Therefore, it has been used as an excellent prognostic factor for hepatic carcinoma [75]. Furthermore, NuSAP has been recognized as a malignancy-risk gene associated with cancer progression in breast cancer patients [76]. Previous reports have shown that the NuSAP gene is highly expressed in aggressive melanomas at the mRNA level compared to its expression in less aggressive cells [77]. It has been found that NuSAP is down-regulated about 2.5-fold in response to methionine stress in CAPAN1 pancreatic adenocarcinoma cells [78]. In a recent study, in vivo knockdown of NuSAP by antisense oligonucleotide morpholino technology altered the migration of neural crest cells in zebrafish embryos [79]. Therefore, diminution of NuSAP expression resulted in the dwindling of cell migration, whereas, NuSAP overexpression encouraged cell migration in zebrafish embryos [79]. These results have demonstrated that NuSAP is associated with apoptosis and cell migration, resulting in carcinogenesis. A recent study has reported that NuSAP expression is up-regulated in oral squamous cell carcinoma (OSCC) at both protein and mRNA levels [80]. NuSAP knockdown resulted in the suppression of cellular proliferation and intensified the anti-tumor activity of paclitaxel by initiating apoptotic pathways [80]. This suggests that NuSAP is an essential biomarker for OSCC, and that NuSAP might serve as an active therapeutic target using NnV.

Activator of $90 \mathrm{kDa}$ heat shock protein ATPase homolog 1 (AHSA1) is known as a chaperone of heat shock $90 \mathrm{kDa}$ (HSP90). It is essential for the stimulation of the ATPase activity of HSP90 [81]. It has also been suggested by other investigators that AHSA1 is up-regulated in osteosarcoma (OS). The silencing of AHSA1 can inhibit cell growth, increase cell apoptosis, and decreased migration and invasion of MG-63 and Saos2 cells [82]. Furthermore, AHSA1 silencing in OS can improve the activity of negative regulators of the Wnt/ $\beta$-catenin signaling pathway, induce cell apoptosis, and reduce cell proliferation [81,82]. AHSA1 may perform an oncological role in OS. It provides an opportunity to establish a potential therapeutic target in OS. In our current work, treatment with $\mathrm{NnV}$ decreased the protein level of AHSA1 in HepG2 cells, further supporting the anticancer activity of NnV.

The adrenal cortex Steroid 21-hydroxylase gene (CYP21A2) catalyzes 17-hydroxyprogesterone (17-OHP) into 11-deoxycortisol (11-DOF) and progesterone into 11-deoxycorticosterone (11-DOC). These steroids are converted into cortisol and aldosterone, respectively. Congenital adrenal hyperplasia $(\mathrm{CAH})$ disorder is caused due to deficiency in the 21-hydroxylase gene (CYP21A2). $\mathrm{CAH}$ is an autosomal recessive disorder which can act as an important factor in the development of adrenocortical tumors. The transcription factor p53 is a significant tumor suppressor that acts as a hemostatic gene, organizing diverse cellular processes. It has been reported that p53 activation in several types of hepatic cells leads to the increased secretion and expression of the 21-hydroxylase gene (CYP21A2). CYP21A2 was identified as a p53 target gene that demonstrates a novel non-cell-autonomous tumor-suppressive regulation mediated by p53, which can maintain organism homeostasis and prevent malignant disease. Interestingly, Steroid 21-hydroxylase (CYP21A2) protein level was incereased after $\mathrm{NnV}$ treatment for 6 or $12 \mathrm{~h}$ in comparison with the control, which hints towards $\mathrm{NnV}$ dependent p53 pathway modulation.

\subsection{Ontological Classification of Differentially Abundant Proteins}

According to gene ontology classification, the 24 identified proteins with altered amounts in $\mathrm{NnV}$ treated HepG2 cells were classified on the basis of molecular function, biological process, protein class, and cellular components. Based on molecular component ontology, the two major functional categories of these proteins were catalytic activity (57\%) and binding (26\%). Some proteins exhibited structural molecule activity $(9 \%)$ and translation regulator or transporter activity $(4 \%)$. In the biological process 
group, most proteins were associated with the metabolic process (42\%), cellular process (29\%), immune system process $(9 \%)$, response to stimulus, biological regulation, cellular component organization or biogenesis, localization, metabolic process, and multicellular organismal process $(4 \%)$. The most important categories of proteins were a response to stimulus $(4 \%)$ and immune system process $(9 \%)$, indicating the nature of $\mathrm{NnV}$. Further these proteins were divided on the basis of functional protein classes; the most abundant class is of nucleic acid binding proteins (23\%). Many proteins belonged to the following protein classes: oxidoreductase and enzyme modulator $(15 \%)$, cytoskeletal protein $(11 \%)$, hydrolase $(8 \%)$, transferase $(8 \%)$, chaperone, transporter, signaling molecule, kinase, isomerase, and ligase $(4 \%)$. In terms of cellular components, the majority of these proteins were localized to the cell part $(40 \%)$, organelle $(33 \%)$, and macromolecular complex (20\%). Only a few proteins were confined to the cell membrane ( $7 \%)$. Among these annotations, the most prevailing terms in the molecular function, biological process, protein class, and cellular components were the catalytic activity (57\%), metabolic process $(42 \%)$, oxidoreductase and enzyme modulator $(15 \%)$, and cell part $(40 \%)$ respectively (Figure 5).

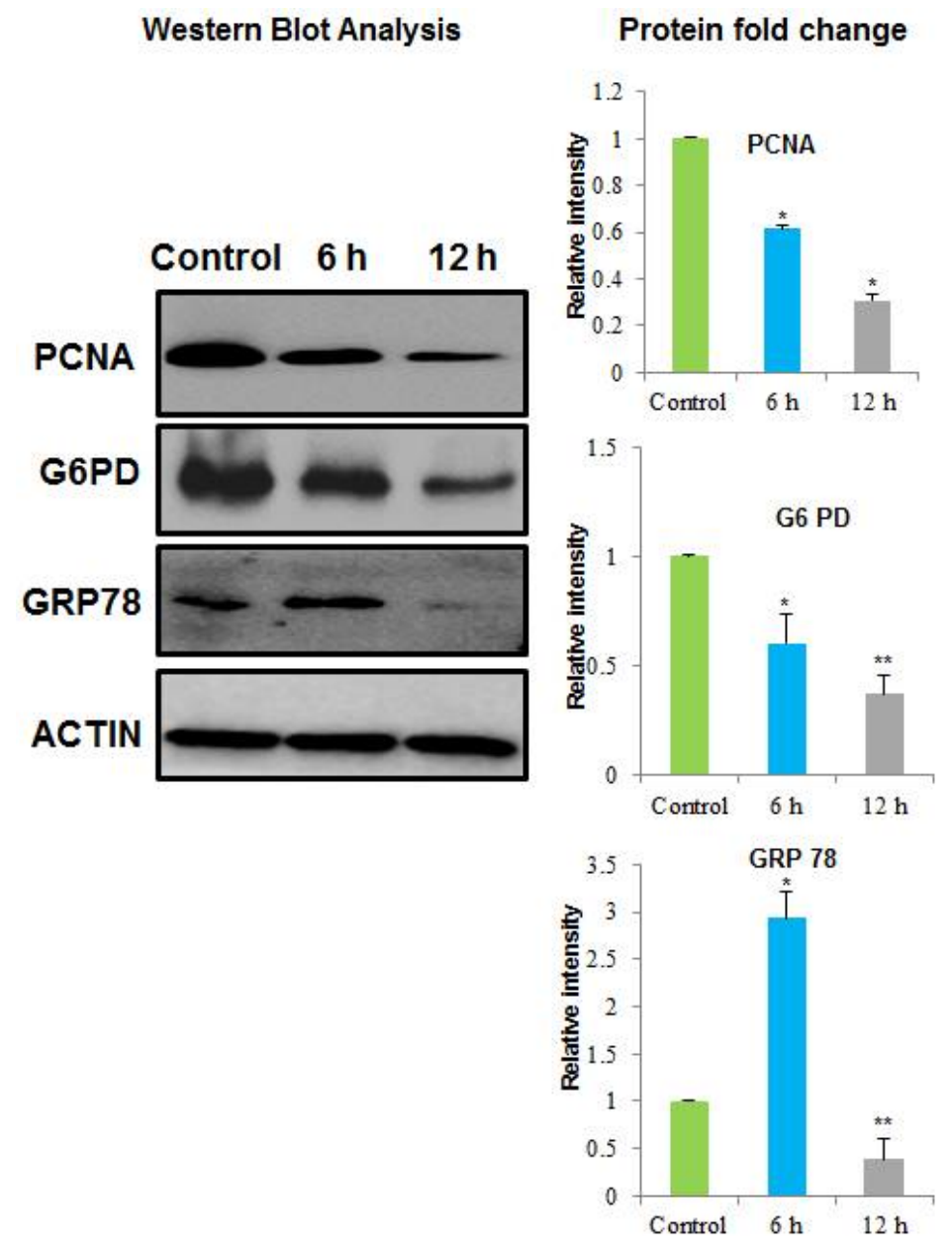

Figure 4. Western blot analyses for confirming the altered protein volumes as identified by MALDI/TOF/MS. Western blots show representative protein bands for GRP78, PCNA, and G6PD; $\beta$-actin was used as the loading control. The densitometric analyses of Western blots were performed by Image Lab software. The bar graph represents the mean \pm SD of the amount of each protein after $\mathrm{NnV}$ treatment in comparison to control. The ${ }^{*}$ asterisk indicates significant differences when compared with the control ${ }^{*} p<0.05,{ }^{* *} p<0.01$. 

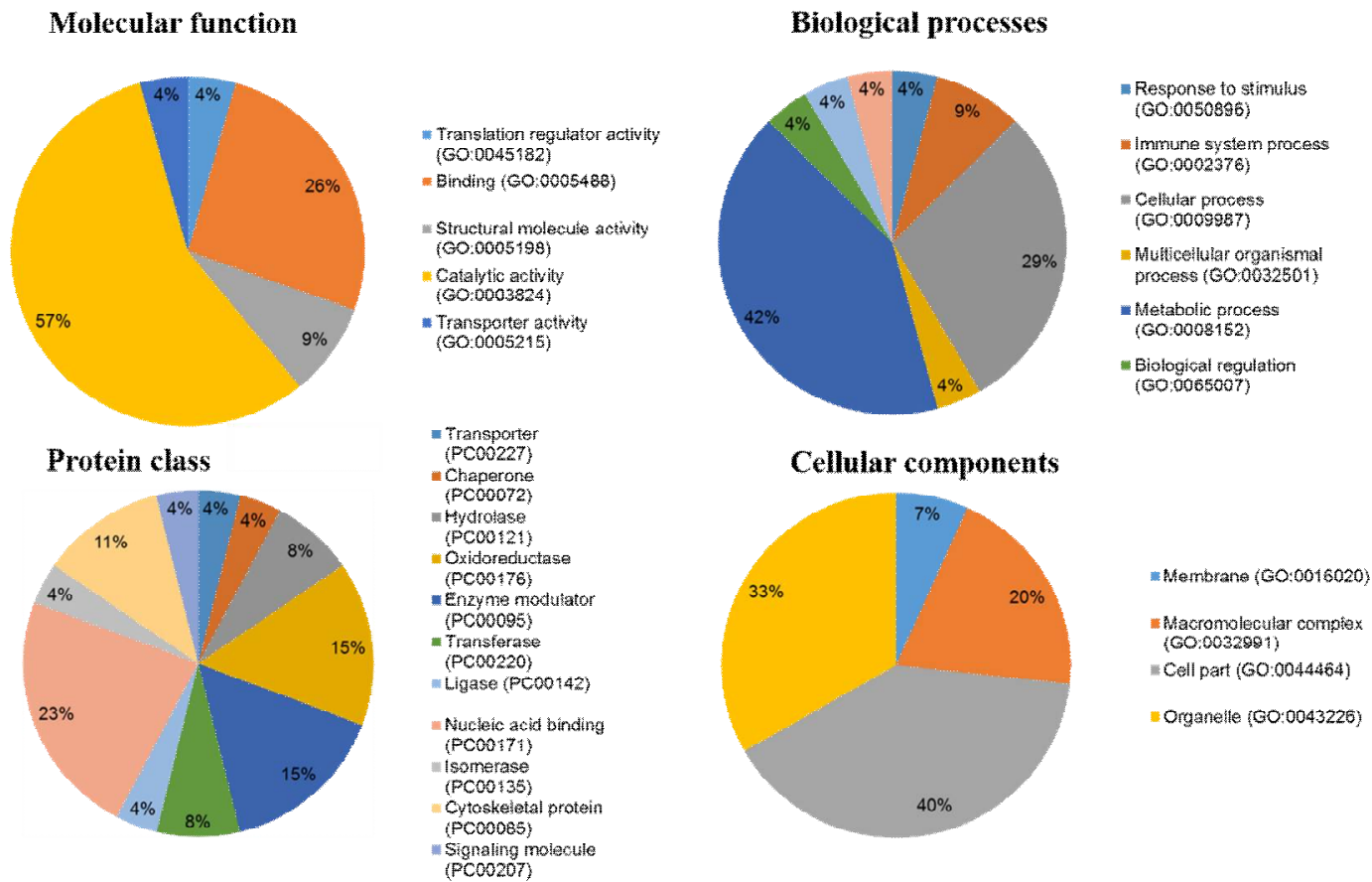

Figure 5. Gene ontology (GO) enrichment analyses of proteins with altered amounts. The identified proteins were categorized into four groups; Molecular function, Biological process, Protein class, and Cellular components, using the Panther classification system (http:www.pantherdb.org/).

Most of the above differentially expressed proteins are involved in cancer regulation. To predict protein-protein interactions and protein complexes, along with putative pathways, the above proteins were subjected to STRING (Search Tool for the Retrieval of Interacting Genes/Proteins) analysis. Generally, proteins were sorted into two different groups, as shown in Figure 6. Both the groups were connected to each other. The first group consisted of PCNA1 and NuSAP1, which are well-known cancer markers, as mentioned above. PCNA1 seems to be in the center of the group and shows interactions with many other proteins involved in the cancer pathway, such as RFC3 and RFC4, which are well-known prognostic cancer markers [83-85]. Another group consists of EEF1G and AHSA1 (Activator of $90 \mathrm{kDa}$ heat shock protein ATPase homolog 1), which were overexpressed in several types of carcinomas and may act as valuable prognostic cancer markers. EEF1G and AHSA1 also appeared to show a tight cluster interaction network with other proteins such as HSPAS and EEF1D. Both HSPA5 (heat shock $70 \mathrm{kDa}$ protein 5) and EEF1D were reported to be expressed at an elevated level in different types of cancers and are associated with tumorigenicity. Also they act as a biological marker for cancer grade, metastases, and prognosis [86-88]. The string interaction and KEGG (Kyoto Encyclopedia of Genes and Genomes) pathway of important cancer marker proteins are shown in Table 3.

To the best of our knowledge, this is the first report showing that $\mathrm{NnV}$ can induce apoptosis of cancer cells at the proteome level. $\mathrm{NnV}$ treatment resulted in diminished levels of proteins involved in DNA replication, cell cycle progression, transcription, tumor cell proliferation, apoptosis resistance, tumor metastasis, and angiogenesis. A few proteins have also been dubbed as oncoproteins due to their overexpression in different types of cancer. Further study on these targets may provide a platform for understanding the molecular mechanisms involved in $\mathrm{NnV}$ induced apoptosis in HepG2 cells. In the near future, more comprehensive efforts need be carried out to understand the detailed mechanisms of $\mathrm{NnV}$ as a cancer therapeutic agent. 


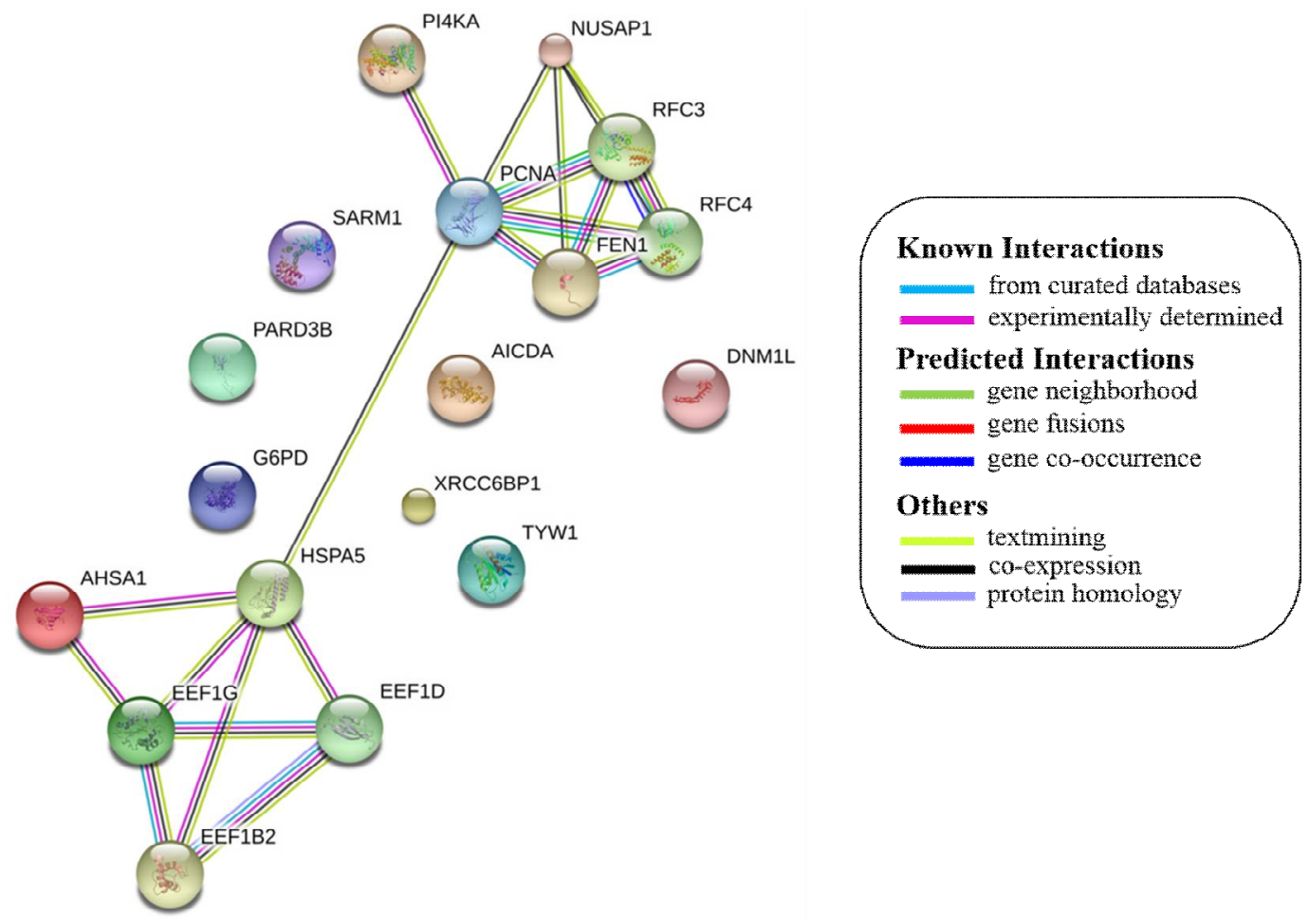

Figure 6. Interaction network of identified differentially expressed proteins using STRING database V 10.5 (http:/ / string-db.org). String pathway analysis of the proteins affected by NnV treatment in HepG2 cells. The types of interactions are represented by different colored lines as shown on the right panel.

Table 3. The String Network interaction of down-regulated cancer marker proteins in N. nomurai venom treated HepG2 cells along with KEGG pathways.

S.NO Protein Name String Interactions


Table 3. Cont

\begin{tabular}{|c|c|c|c|}
\hline S.NO & Protein Name & String Interactions & KEGG Pathways \\
\hline 3 & G6P8 & & $\begin{array}{l}\text { Microbial metabolism in diverse } \\
\text { environments, carbon metabolism, } \\
\text { glycolysis/gluconeogenesis, amino } \\
\text { sugar and nucleotide sugar metabolism, } \\
\text { starch and sucrose metabolism, pentose } \\
\text { phosphate pathway, biosynthesis of } \\
\text { amino acids, and pyruvate metabolism. }\end{array}$ \\
\hline 4 & EEF1G & & $\begin{array}{l}\text { Ribosome Legionellosis } \\
\text { and Legionellosis. }\end{array}$ \\
\hline 5 & DNM1L & & TNF signaling pathway. \\
\hline 6 & NUSAP1 & & $\begin{array}{l}\text { Mitotic sister chromatid, segregation, } \\
\text { mitotic nuclear division, and } \\
\text { cell division. }\end{array}$ \\
\hline 7 & HSP90 & & $\begin{array}{l}\text { Protein processing in endoplasmic } \\
\text { reticulum, antigen processing and } \\
\text { presentation, NOD-like receptor } \\
\text { signaling pathway, } \\
\text { progesterone-mediated oocyte, prostate } \\
\text { cancer, and estrogen signaling pathway. }\end{array}$ \\
\hline
\end{tabular}




\section{Materials and Methods}

\subsection{Sample Collection and Preparation}

The samples of N. nomurai jellyfish were harvested from the sea surrounding Gunsan city, South Korea. Tentacles were dichotomized and moved immediately in ice to the laboratory for further research. Nematocysts were collected using the previously used method with a slight modification [89].The dissected tentacles were washed with cold sea water to separate debris, after that 3 volumes of cold sea water was added and kept for overnight shaking at $4{ }^{\circ} \mathrm{C}$. The tentacles free sea water extract was centrifuged at $1000 \times \mathrm{g}$ for $5 \mathrm{~min}$, the pellet was collected, and then washed three times with sea water. Sedimented tentacles were further autolyzed overnight in fresh sea water at $4{ }^{\circ} \mathrm{C}$, and the autolysis process was reiterated for 3-4 days. Lastly, the settled nematocysts were collected and washed numerous times with fresh sea water. Nematocysts were collected at $500 \times g$ for $5 \mathrm{~min}$. Further pellets (nematocysts) were lyophilized and stored at $-20{ }^{\circ} \mathrm{C}$ until further use.

\subsection{Venom Extraction and Preparation}

Freeze-dried nematocysts were used to isolate the venom using a previously reported method [90], with a minor amendment. Next, venom was sequestered from $50 \mathrm{mg}$ of nematocyst using glass beads (approximately 8000 beads; $0.5 \mathrm{~mm}$ in diameter) and $1 \mathrm{~mL}$ of ice-cold phosphate buffer saline (PBS, $\mathrm{pH}$ 7.4). The above samples were vortexed for $30 \mathrm{~s}$, repeated 5 times with intermittent cooling on ice. The venom extracts were then transferred to new Eppendorf tubes and centrifuged $(22,000 \times g)$ at $4{ }^{\circ} \mathrm{C}$ for $30 \mathrm{~min}$. In the present study, the supernatant was used as jellyfish venom. The Bradford technique [91] was used to quantify the protein concentration of the venom.

\subsection{Cell Culture}

HepG2 cells were bought from the American Type Culture Collection (ATCC, Manassas, VA, USA) and were maintained in Dulbecco's Modified Eagle Medium (DMEM), supplemented with $10 \%$ heat-inactivated fetal bovine serum (FBS), $100 \mu \mathrm{g} / \mathrm{mL}$ Penicillin-Streptomycin-Amphotericin B solution at $37{ }^{\circ} \mathrm{C}$, in a humidified atmosphere with $5 \% \mathrm{CO}_{2}$. Every $2-3$ days the medium was changed, the cell culturing was done until $70 \%$ confluence was attained. The above cells were treated with $1.2 \mu \mathrm{g} / \mathrm{mL} \mathrm{NnV}$ for $6 \mathrm{~h}$ and $12 \mathrm{~h}$.

\subsection{MTT Assay for Cell Viability}

The cell viability was checked by MTT assay to measure the cytotoxicity of NnV in HepG2 cells. HepG2 cells were seeded at a density of $4 \times 10^{4}$ cells/well in 24 -well plates for $24 \mathrm{~h}$. HepG2 cells were treated with different concentrations of $\mathrm{NnV}$ for $24 \mathrm{~h}$. After $24 \mathrm{~h}, 50 \mu \mathrm{L}$ of MTT dye $(5 \mathrm{mg} / \mathrm{mL})$ was added to each well and the cells were further incubated for $3 \mathrm{~h}$ at $37^{\circ} \mathrm{C} .100 \mu \mathrm{L}$ of dimethyl sulfoxide (DMSO) was added to each well after removing the medium. To solubilize the generated formazan salts the 24-well plate was kept on a shaker for $10 \mathrm{~min}$. The optical density at $540 \mathrm{~nm}$ was assessed using a GENios microplate spectrophotometer (PowerWave ${ }^{\mathrm{TM}}$ XS, BioTek Instruments, Inc., Winooski, VT, USA) and was measured to determine the cell viability. The $\mathrm{IC}_{50}$ was determined by Probit analysis [92]. The morphological changes in HepG2 cells were examined after NnV treatment under the phase contrast microscope. HepG2 cells without any treatment were used as the control. MTT assays were performed in triplicates for each dosage and time period.

\subsection{Protein Extraction and Sample Preparation}

For proteome analysis, the human liver cancer cell line HepG2 was seeded in tissue culture plates at $5 \times 10^{4}$ cells $/ \mathrm{mL}$ and incubated overnight, then treated with $\mathrm{NnV}$ for 6 and $12 \mathrm{~h}$. Untreated cells were used as the control sample. At the end of the treatment the cells were washed with ice-cold $1 \times$ phosphate-buffered saline and then homogenized in 2D lysis buffer (7 M Urea, $2 \mathrm{M}$ thiourea, 4\% 
CHAPS (3-[(3-cholamidopropyl) dimethylammonio]-1 propanesulfonate, 10\% DTT, 0.5\% IPG buffer, and $1 \%$ proteinase inhibitor) on ice. Samples were vortexed for $30 \mathrm{~min}$ at $4{ }^{\circ} \mathrm{C}$ and cellular debris were removed by centrifugation $\left(14,000 \mathrm{rpm}\right.$ for $15 \mathrm{~min}$ at $\left.4^{\circ} \mathrm{C}\right)$. Proteins were precipitated by adding equal volumes of $20 \%$ TCA to cell lysis supernatant and incubating for $30 \mathrm{~min}$ on ice. Protein precipitates were centrifuged at 14,000 rpm for $15 \mathrm{~min}$ and the supernatant was discarded. TCA precipitated proteins were washed thrice with ice-cold acetone and centrifuged as above. After that, pellets were vacuum dried for 10-15 min. Subsequently, dried pellets were resuspended in 200-300 $\mu \mathrm{L}$ of sample buffer (7 M urea, $2 \mathrm{M}$ thiourea, and $4 \%$ CHAPS). The sample was determined for protein concentration by Bradford assay and stored at $-80^{\circ} \mathrm{C}$ until further use.

\subsection{Two-Dimensional Gel Electrophoresis and Image Analysis}

For 2D gel electrophoresis, $300 \mu \mathrm{g}$ of protein samples were diluted to $340 \mu \mathrm{L}$ by mixing of the $2 \mathrm{D}$ sample buffer ( $7 \mathrm{M}$ urea, $2 \mathrm{M}$ thiourea, $4 \%$ CHAPS, $10 \mathrm{mg} / \mathrm{mL}$ DTT, $1 \%$ ampholytes, and a few grains of bromophenol blue). These protein samples were applied to the immobiline $18 \mathrm{~cm}$ TM Dry strip ( $\mathrm{pH} 4-7)$, followed by rehydration overnight at room temperature. Isoelectric focusing was conducted using the Ettan IPGphor system (GE Healthcare, Salt Lake City, UT, USA) with the following conditions: $50 \mathrm{~V}$ for 1:00 h, $200 \mathrm{~V}$ for 1:00 h, $500 \mathrm{~V}$ for 0:30 h, gradient $4000 \mathrm{~V}$ for 0:30 h, $4000 \mathrm{~V}$ for 1:00 h, gradient 10,000 V for 1:00 h, 10,000 V for 13:00 h, and $50 \mathrm{~V} \mathrm{3:00} \mathrm{h} \mathrm{at} 20^{\circ} \mathrm{C}$. After Isoelectric focusing, the gel strips were firstly reduced with equilibration buffer $(50 \mathrm{mM}$ Tris- $\mathrm{HCl}(\mathrm{pH} 8.8), 6 \mathrm{M}$ urea, 30\% glycerol, $2 \%$ SDS, and $0.01 \%$ bromophenol blue containing $1 \% w / v$ DTT for $15 \mathrm{~min}$. Again, the gel strips were washed with the same buffer ( $50 \mathrm{mM}$ Tris- $\mathrm{HCl}$ (pH 8.8), $6 \mathrm{M}$ urea, $30 \%$ glycerol, $2 \%$ SDS, and $0.01 \%$ bromophenol blue, replacing the DTT with $2.5 \% w / v$ iodoacetamide) for $15 \mathrm{~min}$. Equilibrated strips were placed over $12 \%$ SDS polyacrylamide gels $(18 \mathrm{~cm} \times 20 \mathrm{~cm} \times 1.5 \mathrm{~mm})$ and then covered with $0.5 \%(w / v)$ agarose made in the SDS electrophoresis running buffer containing a minute amount of bromophenol blue. Electrophoresis was performed in a PROTEAN II xi cell gel electrophoresis unit (Bio-Rad, Hercules, CA, USA) with a constant current of $20 \mathrm{~mA} /$ gel at $20^{\circ} \mathrm{C}$ until the dye front reached the end of the gels. The electrophoresis 2-DE gels were then silver stained, as similar to the method reported by [93]. The 2D gel images were achieved by a Epson perfection V 700 photo scanner (Epson, Suwa, OU, Japan), and image analysis was carried out using Progenesis Same Spots software (Nonlinear Dynamics, Newcastle, UK).

\subsection{In-Gel Digestion}

The protein spots which show differential expression were manually excised from the preparative gels to perform in-gel digestion. In-gel digestion of the proteins was performed according to the method previously described, with some modifications [94]. The gel pieces were washed with destaining solution containing $30 \mathrm{mM}$ potassium ferricyanide and $100 \mathrm{mM} \mathrm{Na}_{2} \mathrm{~S}_{2} \mathrm{O}_{3}(50 \% / 50 \% \mathrm{v} / \mathrm{v})$ for $10 \mathrm{~min}$. For the dehydration step, the gel pieces were rinsed in $100 \%$ acetonitrile for $10 \mathrm{~min}$ and dried using lyophilizer equipment. For the reduction step, $50 \mu \mathrm{L}$ of reduction solution $(10 \mathrm{mM}$ DTT in $100 \mathrm{mM}$ ammonium bicarbonate) was added to the gel pieces, which were incubated for $45 \mathrm{~min}$ at $56{ }^{\circ} \mathrm{C}$. After removing the reduction solution the alkylation solution $(100 \mathrm{mM}$ iodoacetamide in $100 \mathrm{mM}$ ammonium bicarbonate) was added to the gel pieces for $45 \mathrm{~min}$ in the dark, at room temperature. The alkylation solution was removed, and the gel pieces were incubated in trypsin (Promega, Madison, WI, USA) at a final concentration of $2 \mathrm{ng} / \mu \mathrm{L}$ in $10 \mu \mathrm{L}$ of $50 \mathrm{mM} \mathrm{NH}_{4} \mathrm{HCO}_{3}$ and incubated on ice for $45 \mathrm{~min}$. Next, the trypsin was removed, and the proper amount of $50 \mathrm{mM} \mathrm{NH}_{4} \mathrm{HCO}_{3}$ was added to the gel pieces; digestion was carried out overnight at $37^{\circ} \mathrm{C}$. In the extraction step, the tryptic-peptide mixture was pooled with extraction buffer containing $100 \%$ acetonitrile and $50 \%$ trifluoroacetic acid and then lyophilized in a speed vacuum. 


\subsection{MALDI/TOF/MS Analysis and Database Searching}

One microliter of HCCA matrix solution ( $\alpha$-acyano-4-hydroxycinnamic acid) and $1 \mu \mathrm{L}$ of extraction buffer were added to the lyophilized peptide and spotted onto a recently washed MALDI-TOF target plate. Next, the samples were completely crystallized by air drying for $10 \mathrm{~min}$ at room temperature. The samples were analyzed on a Voyager-DE STR mass spectrometer (Applied Biosystems, Franklin Lakes, NJ, USA) using reflection/delayed extraction mode. The mass spectra were acquired over a mass range of 800-3000 Da. To carry out protein identification, the peptide mass fingerprinting data were searched against the SwissProt database using Mascot server (Matrix science http: / / www.matrixscience.com). The following factors were considered throughout the search: taxonomy as Homo sapiens, tryptic digest with one missed cleavage is allowed, peptide mass tolerance of $100 \mathrm{ppm}$ for the fragment ions, fixed modification as the alkylation of the carbamidomethylation, and oxidation of methionine as a variable modification. A protein scores greater than 56 were considered statistically significant $(p<0.05)$.

\subsection{Western Blotting}

HepG2 cells were treated with $\mathrm{NnV}$ for $6 \mathrm{~h}, 12 \mathrm{~h}$ and untreated cells were used as control samples. After treatment, the cells were rinsed thrice with ice-cold phosphate buffered solution (PBS) and the whole cellular protein was lysed on ice with radioimmunoprecipitation assay buffer (RIPA; iNTRON Biotechnology, Seongnam, Gyeonggi-do, Korea) containing a protease inhibitor cocktail. Next, the cell lysates were centrifuged at $22,000 \times g$ for $30 \mathrm{~min}$ at $4{ }^{\circ} \mathrm{C}$, cellular debris were removed, and the supernatant was collected. Protein concentrations of the extracted samples were determined via Bradford assay. Equivalent amounts of protein samples $(10 \mu \mathrm{g})$ were subjected to a 10\% SDS-PAGE at $100 \mathrm{~V}$ and then were transferred to a PVDF membrane (Bio-Rad Laboratories, Hercules, CA, USA) at $25 \mathrm{~V}$ for $30 \mathrm{~min}$. The membranes were blocked with $5 \%$ non-fat milk in Tris-buffered saline and $0.1 \%$ Tween 20 for $2 \mathrm{~h}$ at room temperature. Thereafter, the membranes were incubated with the following respective primary antibodies: GRP 78 (N-20): sc-1050 (1:500, Santa Cruz Biotechnology, Inc., Dallas, TX, USA), PCNA (PC10): sc-56 (1:500, Santa Cruz Biotechnology, Inc.), and Anti-Glucose 6 phosphate Dehydrogenase antibody ab76598 (1:500, Abcam, Cambridge, UK) incubated overnight at $4{ }^{\circ} \mathrm{C}$ temperature. Membranes were also probed with an anti $\beta$-actin (1:2000 Millipore) primary antibody as a loading control. After that, the membranes were washed thrice with TBST buffer for $10 \mathrm{~min}$ and were incubated with the appropriate secondary antibodies (1:2000 dilutions) for $1 \mathrm{~h}$ at RT. Target proteins were developed by enhanced chemiluminescence (ECL, Amersham Biosciences, Buckinghamshire, UK) and scanned using ChemiDoc ${ }^{\mathrm{TM}}$ XRS (Bio-Rad, Hercules, CA, USA). Further quantitative examination was completed with Image $\mathrm{Lab}^{\mathrm{TM}}$ software (Bio-Rad, Hercules, CA, USA).

\subsection{Statistical and Bioinformatics Analysis of Protein Identified by MALDI/TOF/MS}

For the statistical analysis of differentially expressed proteins, One Way Analysis of Variance (ANOVA) was used to evaluate the significance of the difference between the two mean values. $p<0.05$ and $p<0.01$ were considered to be statistically significant. The proteomic data were analyzed using the Panther classification system (http:www.pantherdb.org/) to classify data in terms of molecular function, biological process, protein class, and cellular components [95]. The interaction network of the differentially expressed proteins was performed using the online STRING database V 10.5 (http://string-db.org) [96].

Supplementary Materials: The following are available online at http:/ / www.mdpi.com/2072-6651/10/5/194/s1, Table S1: The proteins with declined relative abundance after NnV treatment, Table S2: The proteins with increased relative abundance after $\mathrm{NnV}$ treatment.

Author Contributions: E.K. conceived and designed the study. I.C. performed the experiments and wrote the manuscript. H.L., M.J.P., Y.H. and C.K. analyzed and interpreted the data. S.S.Y. and J.C. advised jellyfish sampling and species identification. All authors have read and approved the final manuscript. 
Acknowledgments: This work was funded by a National Research Foundation of Korea grant funded by the Korea government (no. NRF-2017R1D1A1B03036005). It has also been partially supported by the Marine Biotechnology Program of the Korea Institute of Marine Science and Technology Promotion (KIMST) funded by the Ministry of Oceans and Fisheries (MOF). This research was also partly supported by the project titled "Development of the methods for controlling and managing marine ecological disturbance-causing and harmful organisms (MEDHO)", funded by the Ministry of Oceans and Fisheries, Korea.

Conflicts of Interest: The authors declare no conflicts of interest.

\section{References}

1. Rocha, L. Analysis of molecular structures and mechanisms for toxins derived from venomous animals. Comput. Biol. Chem. 2016, 61, 8-14. [CrossRef] [PubMed]

2. Rash, L.D.; Hodgson, W.C. Pharmacology and biochemistry of spider venoms. Toxicon 2002, 40, $225-254$. [CrossRef]

3. Ponce, D.; Brinkman, D.L.; Luna-Ramírez, K.; Wright, C.E.; Dorantes-Aranda, J.J. Comparative study of the toxic effects of Chrysaora quinquecirrha (cnidaria: Scyphozoa) and Chironex fleckeri (cnidaria: Cubozoa) venoms using cell-based assays. Toxicon 2015, 106, 57-67. [CrossRef] [PubMed]

4. Liang, X.; Beilei, W.; Ying, L.; Qianqian, W.; Sihua, L.; Yang, W.; Guoyan, L.; Jia, L.; Xuting, Y.; Liming, Z. Cardiovascular effect is independent of hemolytic toxicity of tentacle-only extract from the jellyfish Cyanea capillata. PLoS ONE 2012, 7, e43096. [CrossRef] [PubMed]

5. Ayed, Y.; Chayma, B.; Hayla, A.; Abid, S.; Bacha, H. Is cell death induced by nematocysts extract of medusa Pelagia noctiluca related to oxidative stress? Environ. Toxicol. 2013, 28, 498-506. [CrossRef] [PubMed]

6. Choudhary, I.; Lee, H.; Pyo, M.-J.; Heo, Y.; Bae, S.K.; Kwon, Y.C.; Yoon, W.D.; Kang, C.; Kim, E. Proteomics approach to examine the cardiotoxic effects of Nemopilema nomurai jellyfish venom. J. Proteom. 2015, 128, 123-131. [CrossRef] [PubMed]

7. Kawahara, M.; Uye, S.-i.; Ohtsu, K.; Iizumi, H. Unusual population explosion of the giant jellyfish Nemopilema nomurai (scyphozoa: Rhizostomeae) in East Asian waters. Mar. Ecol. Prog. Ser. 2006, 307, 161-173. [CrossRef]

8. Dong, Z.; Liu, D.; Keesing, J.K. Jellyfish blooms in china: Dominant species, causes and consequences. Mar. Pollut. Bull. 2010, 60, 954-963. [CrossRef] [PubMed]

9. Kawahara, M.; Uye, S.; Burnett, J.; Mianzan, H. Stings of edible jellyfish (Rhopilema hispidum, Rhopilema esculentum and Nemopilema nomurai) in Japanese waters. Toxicon 2006, 48, 713-716. [CrossRef] [PubMed]

10. Kang, C.; Munawir, A.; Cha, M.; Sohn, E.-T.; Lee, H.; Kim, J.-S.; Yoon, W.D.; Lim, D.; Kim, E. Cytotoxicity and hemolytic activity of jellyfish Nemopilema nomurai (scyphozoa: Rhizostomeae) venom. Comp. Biochem. Physiol. Part C Toxicol. Pharmacol. 2009, 150, 85-90. [CrossRef] [PubMed]

11. Heinen, T.E.; da Veiga, A.B.G. Arthropod venoms and cancer. Toxicon 2011, 57, 497-511. [CrossRef] [PubMed]

12. Ménez, A.; Stöcklin, R.; Mebs, D. 'Venomics' or: The Venomous Systems Genome Project; Pergamon: Oxford, UK, 2006.

13. Zargan, J.; Sajad, M.; Umar, S.; Naime, M.; Ali, S.; Khan, H.A. Scorpion (Odontobuthus doriae) venom induces apoptosis and inhibits DNA synthesis in human neuroblastoma cells. Mol. Cell. Biochem. 2011, 348, 173-181. [CrossRef] [PubMed]

14. Ortiz, E.; Gurrola, G.B.; Schwartz, E.F.; Possani, L.D. Scorpion venom components as potential candidates for drug development. Toxicon 2015, 93, 125-135. [CrossRef] [PubMed]

15. Ramezanpour, M.; Da Silva, K.B.; Barbara, J.; Sanderson, S. Venom present in sea anemone (Heteractis magnifica) induces apoptosis in non-small-cell lung cancer a549 cells through activation of mitochondria-mediated pathway. Biotechnol. Lett. 2014, 36, 489. [CrossRef] [PubMed]

16. Park, M.H.; Son, D.J.; Kwak, D.H.; Song, H.S.; Oh, K.-W.; Yoo, H.-S.; Lee, Y.M.; Song, M.J.; Hong, J.T. Snake venom toxin inhibits cell growth through induction of apoptosis in neuroblastoma cells. Arch. Pharm. Res. 2009, 32, 1545-1554. [CrossRef] [PubMed]

17. Abu-Sinna, G.; Esmat, A.Y.; Al-Zahaby, A.-A.S.; Soliman, N.A.; Ibrahim, T.M. Fractionation and characterization of Cerastes cerastes cerastes snake venom and the antitumor action of its lethal and non-lethal fractions. Toxicon 2003, 42, 207-215. [CrossRef]

18. Liu, Z.; Zhao, Y.; Li, J.; Xu, S.; Liu, C.; Zhu, Y.; Liang, S. The venom of the spider Macrothele raveni induces apoptosis in the myelogenous leukemia k562 cell line. Leuk. Res. 2012, 36, 1063-1066. [CrossRef] [PubMed] 
19. Kim, Y.-W.; Chaturvedi, P.K.; Chun, S.N.; Lee, Y.G.; Ahn, W.S. Honeybee venom possesses anticancer and antiviral effects by differential inhibition of hpv e6 and e7 expression on cervical cancer cell line. Oncol. Rep. 2015, 33, 1675-1682. [CrossRef] [PubMed]

20. Sonoda, Y.; Hada, N.; Kaneda, T.; Suzuki, T.; Ohshio, T.; Takeda, T.; Kasahara, T. A synthetic glycosphingolipid-induced antiproliferative effect in melanoma cells is associated with suppression of FAK, Akt, and Erk activation. Biol. Pharm. Bull. 2008, 31, 1279-1283. [CrossRef] [PubMed]

21. Chen, H.M.; Wang, W.; Smith, D.; Chan, S.C. Effects of the anti-bacterial peptide cecropin $b$ and its analogs, cecropins b-1 and b-2, on liposomes, bacteria, and cancer cells. Biochim. Biophys. Acta BBA-Gener. Subj. 1997, 1336, 171-179. [CrossRef]

22. Liu, X.; Xiao, X.-Y.; Shou, Q.-Y.; Yan, J.-F.; Chen, L.; Fu, H.-Y.; Wang, J.-C. Bufalin inhibits pancreatic cancer by inducing cell cycle arrest via the c-myc/nf-kb pathway. J. Ethnopharmacol. 2016, 193, 538-545. [CrossRef] [PubMed]

23. Balamurugan, E.; Reddy, B.V.; Menon, V.P. Antitumor and antioxidant role of Chrysaora quinquecirrha (sea nettle) nematocyst venom peptide against ehrlich ascites carcinoma in swiss albino mice. Mol. Cell. Biochem. 2010, 338, 69-76. [CrossRef] [PubMed]

24. Harada, K.; Maeda, T.; Hasegawa, Y.; Tokunaga, T.; Ogawa, S.; Fukuda, K.; Nagatsuka, N.; Nagao, K.; Ueno, S. Antioxidant activity of the giant jellyfish Nemopilema nomurai measured by the oxygen radical absorbance capacity and hydroxyl radical averting capacity methods. Mol. Med. Rep. 2011, 4, 919-922. [PubMed]

25. Morishige, H.; Sugahara, T.; Nishimoto, S.; Muranaka, A.; Ohno, F.; Shiraishi, R.; Doi, M. Immunostimulatory effects of collagen from jellyfish in vivo. Cytotechnology 2011, 63, 481-492. [CrossRef] [PubMed]

26. Armani, A.; Tinacci, L.; Giusti, A.; Castigliego, L.; Gianfaldoni, D.; Guidi, A. What is inside the jar? Forensically informative nucleotide sequencing (fins) of a short mitochondrial coi gene fragment reveals a high percentage of mislabeling in jellyfish food products. Food Res. Int. 2013, 54, 1383-1393. [CrossRef]

27. Ohta, N.; Sato, M.; Ushida, K.; Kokubo, M.; Baba, T.; Taniguchi, K.; Urai, M.; Kihira, K.; Mochida, J. Jellyfish mucin may have potential disease-modifying effects on osteoarthritis. BMC Biotechnol. 2009, 9, 98. [CrossRef] [PubMed]

28. Lee, H.; Bae, S.K.; Kim, M.; Pyo, M.J.; Kim, M.; Yang, S.; Won, C.-K.; Yoon, W.D.; Han, C.H.; Kang, C.; et al. Anticancer effect of Nemopilema nomurai jellyfish venom on HepG2 cells and a tumor xenograft animal model. Evid.-Based Complement. Altern. Med. 2017, 2017. [CrossRef] [PubMed]

29. Moldovan, G.-L.; Pfander, B.; Jentsch, S. Pcna controls establishment of sister chromatid cohesion during s phase. Mol. Cell 2006, 23, 723-732. [CrossRef] [PubMed]

30. Kim, B.J.; Lee, H. Lys-110 is essential for targeting pcna to replication and repair foci, and the k110a mutant activates apoptosis. Biol. Cell 2008, 100, 675-686. [CrossRef] [PubMed]

31. Stoimenov, I.; Helleday, T. Pcna on the Crossroad of Cancer; Portland Press Limited: London, UK, 2009.

32. Kato, T.; Kameoka, S.; Kimura, T.; Nishikawa, T.; Kobayashi, M. C-erbb-2 and pena as prognostic indicators of long-term survival in breast cancer. Anticancer Res. 2002, 22, 1097-1103. [PubMed]

33. Kuang, R.-G.; Wu, H.-X.; Hao, G.-X.; Wang, J.-W.; Zhou, C.-J. Expression and significance of igf-2, pcna, mmp-7, and alpha-actin in gastric carcinoma with lauren classification. Turk. J. Gastroenterol. 2013, 24, 99-108. [CrossRef] [PubMed]

34. Kimos, M.C.; Wang, S.; Borkowski, A.; Yang, G.Y.; Yang, C.S.; Perry, K.; Olaru, A.; Deacu, E.; Sterian, A.; Cottrell, J. Esophagin and proliferating cell nuclear antigen (pcna) are biomarkers of human esophageal neoplastic progression. Int. J. Cancer 2004, 111, 415-417. [CrossRef] [PubMed]

35. Li, T.; Dong, Z.R.; Guo, Z.Y.; Wang, C.H.; Zhi, X.T.; Zhou, J.W.; Li, D.K.; Chen, Z.T.; Chen, Z.Q.; Hu, S.Y. Mannose-mediated inhibitory effects of pa-msha on invasion and metastasis of hepatocellular carcinoma via egfr/akt/ikb $\beta /$ nf-kb pathway. Liver Int. 2015, 35, 1416-1429. [CrossRef] [PubMed]

36. Tan, Z.; Wortman, M.; Dillehay, K.L.; Seibel, W.L.; Evelyn, C.R.; Smith, S.J.; Malkas, L.H.; Zheng, Y.; Lu, S.; Dong, Z. Small-molecule targeting of proliferating cell nuclear antigen chromatin association inhibits tumor cell growth. Mol. Pharmacol. 2012, 81, 811-819. [CrossRef] [PubMed]

37. Li, X.; Zhang, K.; Li, Z. Unfolded protein response in cancer: The physician's perspective. J. Hematol. Oncol. 2011, 4, 8. [CrossRef] [PubMed]

38. Lee, A.S. The er chaperone and signaling regulator grp78/bip as a monitor of endoplasmic reticulum stress. Methods 2005, 35, 373-381. [CrossRef] [PubMed] 
39. Li, J.; Lee, A.S. Stress induction of grp78/bip and its role in cancer. Curr. Mol. Med. 2006, 6, 45-54. [CrossRef] [PubMed]

40. Li, Z.; Li, Z. Glucose regulated protein 78: A critical link between tumor microenvironment and cancer hallmarks. Biochim. Biophys. Acta (BBA)-Rev. Cancer 2012, 1826, 13-22. [CrossRef] [PubMed]

41. Lee, A.S. Grp78 induction in cancer: Therapeutic and prognostic implications. Cancer Res. 2007, 67, 3496-3499. [CrossRef] [PubMed]

42. Yang, L.; Yang, S.; Liu, J.; Wang, X.; Ji, J.; Cao, Y.; Lu, K.; Wang, J.; Gao, Y. Expression of grp78 predicts taxane-based therapeutic resistance and recurrence of human gastric cancer. Exp. Mol. Pathol. 2014, 96, 235-241. [CrossRef] [PubMed]

43. Banerjee, H.; Hyman, G.; Evans, S.; Manglik, V.; Gwebu, E.; Banerjee, A.; Vaughan, D.; Medley, J.; Krauss, C.; Wilkins, J. Identification of the transmembrane glucose regulated protein 78 as a biomarker for the brain cancer glioblastoma multiforme by gene expression and proteomic studies. J. Membr. Sci. Technol. 2014, 4. [CrossRef]

44. Shimizu, A.; Kaira, K.; Yasuda, M.; Asao, T.; Ishikawa, O. Clinical and pathological significance of er stress marker (bip/grp78 and perk) expression in malignant melanoma. Pathol. Oncol. Res. 2017, 23, 111-116. [CrossRef] [PubMed]

45. Kaira, K.; Toyoda, M.; Shimizu, A.; Mori, K.; Shino, M.; Sakakura, K.; Takayasu, Y.; Takahashi, K.; Oyama, T.; Asao, T. Expression of er stress markers (grp78/bip and perk) in patients with tongue cancer. Neoplasma 2015, 63, 588-594. [CrossRef] [PubMed]

46. Fu, Y.; Lee, A.S. Glucose regulated proteins in cancer progression, drug resistance and immunotherapy. Cancer Biol. Ther. 2006, 5, 741-744. [CrossRef] [PubMed]

47. Zhang, J.; Jiang, Y.; Jia, Z.; Li, Q.; Gong, W.; Wang, L.; Wei, D.; Yao, J.; Fang, S.; Xie, K. Association of elevated grp78 expression with increased lymph node metastasis and poor prognosis in patients with gastric cancer. Clin. Exp. Metast. 2006, 23, 401-410. [CrossRef] [PubMed]

48. Boros, L.G.; Puigjaner, J.; Cascante, M.; Lee, W.-N.P.; Brandes, J.L.; Bassilian, S.; Yusuf, F.I.; Williams, R.D.; Muscarella, P.; Melvin, W.S. Oxythiamine and dehydroepiandrosterone inhibit the nonoxidative synthesis of ribose and tumor cell proliferation. Cancer Res. 1997, 57, 4242-4248. [PubMed]

49. Furuta, E.; Okuda, H.; Kobayashi, A.; Watabe, K. Metabolic genes in cancer: Their roles in tumor progression and clinical implications. Biochim. Biophys. Acta (BBA)-Rev. Cancer 2010, 1805, 141-152. [CrossRef] [PubMed]

50. Rao, X.; Duan, X.; Mao, W.; Li, X.; Li, Z.; Li, Q.; Zheng, Z.; Xu, H.; Chen, M.; Wang, P.G. O-glcnacylation of g6pd promotes the pentose phosphate pathway and tumor growth. Nat. Commun. 2015, 6, 8468. [CrossRef] [PubMed]

51. Koudstaal, J.; Makkink, B.; Overdiep, S.H. Enzyme histochemical pattern in human tumours-ii. Oxidoreductases in carcinoma of the colon and the breast. Eur. J. Cancer 1975, 11, 111-114. [CrossRef]

52. Batetta, B.; Pulisci, D.; Bonatesta, R.; Sanna, F.; Piras, S.; Mulas, M.; Spano, O.; Putzolu, M.; Broccia, G.; Dessi', S. G6pd activity and gene expression in leukemic cells from g6pd-deficient subjects. Cancer Lett. 1999, 140, 53-58. [CrossRef]

53. Hu, T.; Zhang, C.; Tang, Q.; Su, Y.; Li, B.; Chen, L.; Zhang, Z.; Cai, T.; Zhu, Y. Variant g6pd levels promote tumor cell proliferation or apoptosis via the stat $3 / 5$ pathway in the human melanoma xenograft mouse model. BMC Cancer 2013, 13, 251. [CrossRef] [PubMed]

54. Hu, T.; Li, Y.-S.; Chen, B.; Chang, Y.-F.; Liu, G.-C.; Hong, Y.; Chen, H.-L.; Xiyang, Y.-B. Elevated glucose-6-phosphate dehydrogenase expression in the cervical cancer cases is associated with the cancerigenic event of high-risk human papillomaviruses. Exp. Biol. Med. 2015, 240, 1287-1297. [CrossRef] [PubMed]

55. Nna, E.; Tothill, I.E.; Ludeman, L.; Bailey, T. Endogenous control genes in prostate cells: Evaluation of gene expression using 'real-time'quantitative polymerase chain reaction. Med. Princ. Pract. 2010, 19, 433-439. [CrossRef] [PubMed]

56. Hughes, E.C. The effect of enzymes upon metabolism, storage, and release of carbohydrates in normal and abnormal endometria. Cancer 1976, 38, 487-502. [CrossRef]

57. Kuo, W.-Y.; Tang, T.K. Effects of g6pd overexpression in nih3t3 cells treated with tert-butyl hydroperoxide or paraquat. Free Radic. Biol. Med. 1998, 24, 1130-1138. [CrossRef]

58. Kuo, W.Y.; Lin, J.Y.; Tang, T.K. Human glucose-6-phosphate dehydrogenase (g6pd) gene transforms NIH 3t3 cells and induces tumors in nude mice. Int. J. Cancer 2000, 85, 857-864. [CrossRef] 
59. Hu, H.; Ding, X.; Yang, Y.; Zhang, H.; Li, H.; Tong, S.; An, X.; Zhong, Q.; Liu, X.; Ma, L. Changes in glucose-6-phosphate dehydrogenase expression results in altered behavior of HBV-associated liver cancer cells. Am. J. Physiol.-Gastrointest. Liver Physiol. 2014, 307, G611-G622. [CrossRef] [PubMed]

60. Fang, Z.; Jiang, C.; Feng, Y.; Chen, R.; Lin, X.; Zhang, Z.; Han, L.; Chen, X.; Li, H.; Guo, Y. Effects of g6pd activity inhibition on the viability, ROS generation and mechanical properties of cervical cancer cells. Biochim. Biophys. Acta (BBA)-Mol. Cell Res. 2016, 1863, 2245-2254. [CrossRef] [PubMed]

61. Riis, B.; Rattan, S.I.; Clark, B.F.; Merrick, W.C. Eukaryotic protein elongation factors. Trends Biochem. Sci. 1990, 15, 420-424. [CrossRef]

62. Mathur, S.; Cleary, K.R.; Inamdar, N.; Kim, Y.H.; Steck, P.; Frazier, M.L. Overexpression of elongation factor-1 $\gamma$ protein in colorectal carcinoma. Cancer 1998, 82, 816-821. [CrossRef]

63. Al-Maghrebi, M.; Anim, J.T.; Olalu, A.A. Up-regulation of eukaryotic elongation factor-1 subunits in breast carcinoma. Anticancer Res. 2005, 25, 2573-2577. [PubMed]

64. Mimori, K.; Mori, M.; Akiyoshi, T.; Tanaka, S.; Sugimachi, K. The overexpression of elongation factor 1 gamma mrna in gastric carcinoma. Cancer 1995, 75, 1446-1449. [CrossRef]

65. Shuda, M.; Kondoh, N.; Tanaka, K.; Ryo, A.; Wakatsuki, T.; Hada, A.; Goseki, N.; Igari, T.; Hatsuse, K.; Aihara, T. Enhanced expression of translation factor mRNAs in hepatocellular carcinoma. Anticancer Res. 2000, 20, 2489-2494. [PubMed]

66. Lew, Y.; Jones, D.V.; Mars, W.M.; Evans, D.; Byrd, D.; Frazier, M.L. Expression of elongation factor-1 gamma-related sequence in human pancreatic cancer. Pancreas 1992, 7, 144-152. [CrossRef] [PubMed]

67. Mimori, K.; Mori, M.; Inoue, H.; Ueo, H.; Mafune, K.; Akiyoshi, T.; Sugimachi, K. Elongation factor 1 gamma mRNA expression in oesophageal carcinoma. Gut 1996, 38, 66-70. [CrossRef] [PubMed]

68. Qian, W.; Wang, J.; Van Houten, B. The Role of Dynamin-Related Protein 1 in Cancer Growth: A Promising Therapeutic Target? Taylor \& Francis: Abingdon, UK, 2013.

69. Inoue-Yamauchi, A.; Oda, H. Depletion of mitochondrial fission factor drp1 causes increased apoptosis in human colon cancer cells. Biochem. Biophys. Res. Commun. 2012, 421, 81-85. [CrossRef] [PubMed]

70. Zhao, J.; Zhang, J.; Yu, M.; Xie, Y.; Huang, Y.; Wolff, D.W.; Abel, P.W.; Tu, Y. Mitochondrial dynamics regulates migration and invasion of breast cancer cells. Oncogene 2013, 32, 4814-4824. [CrossRef] [PubMed]

71. Rehman, J.; Zhang, H.J.; Toth, P.T.; Zhang, Y.; Marsboom, G.; Hong, Z.; Salgia, R.; Husain, A.N.; Wietholt, C.; Archer, S.L. Inhibition of mitochondrial fission prevents cell cycle progression in lung cancer. FASEB J. 2012, 26, 2175-2186. [CrossRef] [PubMed]

72. Parone, P.A.; Da Cruz, S.; Tondera, D.; Mattenberger, Y.; James, D.I.; Maechler, P.; Barja, F.; Martinou, J.-C. Preventing mitochondrial fission impairs mitochondrial function and leads to loss of mitochondrial DNA. PLoS ONE 2008, 3, e3257. [CrossRef] [PubMed]

73. Raemaekers, T.; Ribbeck, K.; Beaudouin, J.; Annaert, W.; Van Camp, M.; Stockmans, I.; Smets, N.; Bouillon, R.; Ellenberg, J.; Carmeliet, G. NuSAP, a novel microtubule-associated protein involved in mitotic spindle organization. J. Cell Biol. 2003, 162, 1017-1029. [CrossRef] [PubMed]

74. Iyer, J.; Moghe, S.; Furukawa, M.; Tsai, M.Y. What's Nu(SAP) in mitosis and cancer? Cell. Signal. 2011, 23, 991-998. [CrossRef] [PubMed]

75. Satow, R.; Shitashige, M.; Kanai, Y.; Takeshita, F.; Ojima, H.; Jigami, T.; Honda, K.; Kosuge, T.; Ochiya, T.; Hirohashi, S.; et al. Combined functional genome survey of therapeutic targets for hepatocellular carcinoma. Clin. Cancer Res. 2010, 16, 2518-2528. [CrossRef] [PubMed]

76. Chen, D.T.; Nasir, A.; Culhane, A.; Venkataramu, C.; Fulp, W.; Rubio, R.; Wang, T.; Agrawal, D.; McCarthy, S.M.; Gruidl, M.; et al. Proliferative genes dominate malignancy-risk gene signature in histologically-normal breast tissue. Breast Cancer Res. Treat. 2010, 119, 335-346. [CrossRef] [PubMed]

77. Ryu, B.; Kim, D.S.; Deluca, A.M.; Alani, R.M. Comprehensive expression profiling of tumor cell lines identifies molecular signatures of melanoma progression. PLoS ONE 2007, 2, e594. [CrossRef] [PubMed]

78. Kokkinakis, D.M.; Liu, X.; Neuner, R.D. Modulation of cell cycle and gene expression in pancreatic tumor cell lines by methionine deprivation (methionine stress): Implications to the therapy of pancreatic adenocarcinoma. Mol. Cancer Ther. 2005, 4, 1338-1348. [CrossRef] [PubMed]

79. Nie, J.; Wang, H.; He, F.; Huang, H. NuSAP1 is essential for neural crest cell migration in zebrafish. Protein Cell 2010, 1, 259-266. [CrossRef] [PubMed] 
80. Okamoto, A.; Higo, M.; Shiiba, M.; Nakashima, D.; Koyama, T.; Miyamoto, I.; Kasama, H.; Kasamatsu, A.; Ogawara, K.; Yokoe, H.; et al. Down-regulation of nucleolar and spindle-associated protein 1 (NuSAP1) expression suppresses tumor and cell proliferation and enhances anti-tumor effect of paclitaxel in oral squamous cell carcinoma. PLoS ONE 2015, 10, e0142252. [CrossRef] [PubMed]

81. Shao, J.; Wang, L.; Zhong, C.; Qi, R.; Li, Y. AHSA1 regulates proliferation, apoptosis, migration, and invasion of osteosarcoma. Biomed. Pharmacother. 2016, 77, 45-51. [CrossRef] [PubMed]

82. Panaretou, B.; Siligardi, G.; Meyer, P.; Maloney, A.; Sullivan, J.K.; Singh, S.; Millson, S.H.; Clarke, P.A.; Naaby-Hansen, S.; Stein, R.; et al. Activation of the ATPase activity of hsp90 by the stress-regulated cochaperone aha1. Mol. Cell 2002, 10, 1307-1318. [CrossRef]

83. Shen, H.; Cai, M.; Zhao, S.; Wang, H.; Li, M.; Yao, S.; Jiang, N. Overexpression of rfc3 is correlated with ovarian tumor development and poor prognosis. Tumour Biol. 2014, 35, 10259-10266. [CrossRef] [PubMed]

84. Arai, M.; Kondoh, N.; Imazeki, N.; Hada, A.; Hatsuse, K.; Matsubara, O.; Yamamoto, M. The knockdown of endogenous replication factor $\mathrm{c} 4$ decreases the growth and enhances the chemosensitivity of hepatocellular carcinoma cells. Liver Int. 2009, 29, 55-62. [CrossRef] [PubMed]

85. Jung, H.M.; Choi, S.J.; Kim, J.K. Expression profiles of sv40-immortalization-associated genes upregulated in various human cancers. J. Cell. Biochem. 2009, 106, 703-713. [CrossRef] [PubMed]

86. Nadin, S.B.; Sottile, M.L.; Montt-Guevara, M.M.; Gauna, G.V.; Daguerre, P.; Leuzzi, M.; Gago, F.E.; Ibarra, J.; Cuello-Carrion, F.D.; Ciocca, D.R.; et al. Prognostic implication of hspa (hsp70) in breast cancer patients treated with neoadjuvant anthracycline-based chemotherapy. Cell Stress Chaperones 2014, 19, 493-505. [CrossRef] [PubMed]

87. Flores, I.L.; Kawahara, R.; Miguel, M.C.; Granato, D.C.; Domingues, R.R.; Macedo, C.C.; Carnielli, C.M.; Yokoo, S.; Rodrigues, P.C.; Monteiro, B.V.; et al. Eef1d modulates proliferation and epithelial-mesenchymal transition in oral squamous cell carcinoma. Clin. Sci. 2016, 130, 785-799. [CrossRef] [PubMed]

88. Ogawa, K.; Utsunomiya, T.; Mimori, K.; Tanaka, Y.; Tanaka, F.; Inoue, H.; Murayama, S.; Mori, M. Clinical significance of elongation factor-1 delta mRNA expression in oesophageal carcinoma. Br. J. Cancer 2004, 91, 282-286. [CrossRef] [PubMed]

89. Bloom, D.A.; Burnett, J.W.; Alderslade, P. Partial purification of box jellyfish (Chironex fleckeri) nematocyst venom isolated at the beachside. Toxicon 1998, 36, 1075-1085. [CrossRef]

90. Carrette, T.; Seymour, J. A rapid and repeatable method for venom extraction from cubozoan nematocysts. Toxicon 2004, 44, 135-139. [CrossRef] [PubMed]

91. Bradford, M.M. A rapid and sensitive method for the quantitation of microgram quantities of protein utilizing the principle of protein-dye binding. Anal. Biochem. 1976, 72, 248-254. [CrossRef]

92. Finney, D.J.; Tattersfield, F. Probit Analysis, 2nd ed.; Finney, D.J., Ed.; Cambridge University Press: New York, NY, USA, 1952.

93. Mortz, E.; Krogh, T.N.; Vorum, H.; Gorg, A. Improved silver staining protocols for high sensitivity protein identification using matrix-assisted laser desorption/ionization-time of flight analysis. Proteomics 2001, 1, 1359-1363. [CrossRef]

94. Shevchenko, A.; Jensen, O.N.; Podtelejnikov, A.V.; Sagliocco, F.; Wilm, M.; Vorm, O.; Mortensen, P.; Shevchenko, A.; Boucherie, H.; Mann, M. Linking genome and proteome by mass spectrometry: Large-scale identification of yeast proteins from two dimensional gels. Proc. Natl. Acad. Sci. USA 1996, 93, 14440-14445. [CrossRef] [PubMed]

95. Mi, H.; Muruganujan, A.; Casagrande, J.T.; Thomas, P.D. Large-scale gene function analysis with the panther classification system. Nat. Protoc. 2013, 8, 1551-1566. [CrossRef] [PubMed]

96. Szklarczyk, D.; Morris, J.H.; Cook, H.; Kuhn, M.; Wyder, S.; Simonovic, M.; Santos, A.; Doncheva, N.T.; Roth, A.; Bork, P.; et al. The string database in 2017: Quality-controlled protein-protein association networks, made broadly accessible. Nucleic Acids Res. 2017, 45, D362-D368. [CrossRef] [PubMed]

(C) 2018 by the authors. Licensee MDPI, Basel, Switzerland. This article is an open access article distributed under the terms and conditions of the Creative Commons Attribution (CC BY) license (http:/ / creativecommons.org/licenses/by/4.0/). 